\title{
BAJO SEDIMENTS AND THE HYDRAULIC SYSTEM OF CALAKMUL, CAMPECHE, MEXICO
}

\author{
Joel D. Gunn, ${ }^{\mathrm{a}}$ John E. Foss, ${ }^{\mathrm{b}}$ William J. Folan, ${ }^{\mathrm{c}}$ Maria del Rosario Domínguez Carrasco, ${ }^{\mathrm{c}}$ \\ and Betty B. Faust ${ }^{d}$ \\ ${ }^{a}$ New South Associates, Inc., 1232 S. 5th Street, Suite A, Mebane, NC 27302, USA \\ 'boils International, 609 Laurel Valley Road, Knoxville, TN 37922, USA \\ 'Centro de Investigaciones Históricas y Sociales, Universidad Autónoma de Campeche, Av. Agustin Melgar, Campeche, Mexico \\ dDepartamento de Ecologia Humana CINVESTAV-Unidad Merida, A. P. 73, Km. 6 Antiq. Carr. a Pregreso, Merida, Mexico
}

\begin{abstract}
Maya Lowlands climate researchers have set aside earlier beliefs that Maya civilization flourished in an unchanging environment. Analyses of river discharge, weather patterns, lake-bottom sediments, and settlement patterns reveal a highly variable climate, considerable diversity in local geology and soils, and a wide range of cultural adaptations tailored to distinctive subregional settings. Significant knowledge gaps remain. Among the unanswered questions is how cities in the elevated interior were maintained without natural, permanent bodies of water even during equitable climatic conditions, much less through the episodes of severe drought that have become apparent in studies of past climates. The research reported in this article lays the groundwork for climate studies in the southwestern Yucatan Peninsula.
\end{abstract}

Over the past two decades, we have explored diverse horticultural customs and variability in river discharge in the state of Campeche, Mexico, and their teleconnected relationships with global climatechange issues (Folan et al. 1983; Gunn and Adams 1981; Gunn and Folan 2000; Gunn et al. 1994, 1995). The Candelaria River system, which drains about half of Campeche, shows the strongest statistical relationship to cyclical global-climate parameters of any watershed we have examined anywhere in the world thus far (Gunn and Folan 2000). The reason for this exceptional sensitivity to global climate seems to be its watercourse, which includes vast swamps in the coastal plain. The swamps act as solar collectors amplifying variations in solar radiation (Gunn 1991, 1997; Gunn et al. 1994, 1995). Additional influences stem from the relocation and size of the Bermuda-Azores subtropical high (Folan 1981; Folan et al. 1983; Gill 1995, 2000) and other global-scale parameters. These variations enunciate a rhythm of variations in dry-wet season duration that governs the productivity of agriculture (Gunn et al. 1995). Although lake-bottom cores from other regions of the peninsula (e.g., Dunning et al. 1998; Hodell et al. 1995; Leyden 1987; Leyden et al. 1994; Whitmore et al. 1996) appear broadly to support the Campeche model, long-period paleoclimatic measures are only now being obtained for the western half of the peninsula. In this article, we first address some theoretical issues concerning moisture and drought that frame climate change in the western peninsula, especially with regard to large, interior cities. Then we turn to a field study of interior bajo (or seasonal swamp) sediments through pedology and geochemistry. Although our first concern is to determine the suitability of sediments in the high bajos for climate studies, we do find some interesting baseline information on the habitats of interior Maya cities.
The modern Maya may provide some of the ecological concepts necessary to understand the ancient Maya. On the cultural side of the modeling equations, modern Maya continue to practice a tradition of tropical gardening (milpa). Maya milperos adapt to the phases of this climatic rhythm through a sophisticated system of planting strategies (Folan and Gallegos 1992, 1998) governed by a suite of calendrical rituals (Faust and Gunn 2000) with variations adapted to local differences in geology and soil. The local milpa custom is a highly productive variety of tropical gardening that yields a well-balanced and rich diet that includes maize, beans, squash, sweet potatoes, yucca, yams, and chilies. Protein is provided by the combination of maize and beans, complemented by small domestic animals raised in the house yard and game acquired through a predator-saturation strategy.

In the second half of this article, we report the collection and analysis of baseline pedological and climatic field data from the upper Candelaria River system in the Campeche interior from investigations carried out in 1999. Two other projects are exploring the middle (Alfred Siemens, personal communication 2001) and lower (Laguna de Terminos, Day 2000, field notes) Candelaria River watershed for similar data on the ocean-side outputs of the river system under differing climate conditions through time. Our previous studies were oriented toward modeling the sensitivity of the modern (since 1958) river system to global change by means of river discharge rates (Gunn and Folan 2000; Gunn et al. 1994, 1995). In the 1999 study, we studied local climate through sedimentological inputs to bajos, or seasonal swamps, in the upper Candelaria to test and elaborate our climate model.

The apparent importance of water to the drought-vulnerable cities of the interior basin suggests that the ecology of cities next

***Reprinted with permission. No further reproduction is authorized without written permission from Cambridge University Press. This version of the document is not the version of record. Figures and/or pictures may be missing from this format of the document.*** 
to bajos, not lakes, was an important gap in the general understanding of the appearance and disappearance of the spectacular Maya civilization of the first millennia B.C. and A.D. To address this question, we prepared a proposal for the National Geographic Society to study the ecology and sedimentation of the bajos in the northern Peten subregion of interior Campeche, Mexico.

The first part of this article begins the process of addressing how the ancient Maya managed to build large interior cites during the Preclassic and Classic periods and maintain them-or, in some cases, not maintain them-in the face of significant global and regional change. It is no mystery that large populations could maintain themselves on the coast of Campeche, which includes areas of very rich offshore and estuarine habitat, as in the case of the important city and port of Champoton, Campeche (Folan, Morales Lopez, Domínguez, Ruiz, González, Gunn, Folan, Barredo, and Hernández 2001) and clay-lined valleys. How cities were maintained in the elevated interior, however, is a feat that deserves attention. In previous publications (Gunn and Folan 2000; Gunn et al. 1993), we noted that southwestern Maya Lowlands urbanism seems to have an episodic character that oscillates between florescence and decline, occurring not just once during the so-called ninth-century Maya Collapse, but on at least one or more other occasions. Richard E. W. Adams (1991) believes this generally to be the case in the lowlands. Thus, whereas our previous studies of global change were oriented toward Campeche agriculture, this research is concerned with global change and urban organization.

\section{SETTING}

Under the scrutiny of inspection, old concepts of the Yucatan Peninsula as a uniform, swampy, tropical forest have given way to that of a highly varied landscape (Dunning 1996; Dunning et al. 2000; Gates 1999; Murray and Weide 1967). The state of Campeche in the southwestern Yucatan Peninsula is, in fact, walled off from the rest of the peninsula by the Puuc Hills along its northeastern border and the Xbonil Hills (Sierrita de Ticul) along the eastern edge (Figure 1). Elevations in this wall rise to more than $300 \mathrm{~m}$. Though not as formidable as mountains, these hills would have limited and differentiated contact between sides of the peninsula and channeled cross-peninsular trade relations in the pre-Columbian era as they do now. West of this hilly wall, a province of small basins and ridges steps down from the hills to the coast of the Bay of Campeche (Figure 2). The Calakmul Basin is the most interior of these basins and is drained in the south by the El TomatillalCandelaria river system, and in the north by the DesempeñoChampoton river system; farther north is a smaller, clay-lined basin, the Edzna Valley, found on the eastern edge of the coastal plain and drained by the seasonal Green River (Río Verde) that flows into the Gulf of Mexico, north of Campeche City.

The Calakmul Basin is divided at the city of Calakmul by a transverse ridge that separates two seasonal swamps. The southwestern part is the El Laberinto bajo, and to the northeast of the ridge is the El Ramonal bajo.

\section{COMPARING LARGE CITIES}

Large Maya cities of the Preclassic and Classic periods speckle the coastal plain and interior basins. Our immediate concerns will focus on the cities of Edzna in the coastal plain and Calakmul in the interior basin. The contrast between the two cities, as we shall see, could not be greater, and the differences are highly illuminating of the processes used to maintain cities in the interior, where cities would have existed only with difficulty.

The cities of Edzna and Calakmul, for all practical purposes, are as different as Venice and Rome. Although both cities seem to have developed as urban centers during the Late Preclassic (400 B.C.-A.D. 250), the distinction between concave and convex water systems made by Vernon Scarborough (1998) applies within the same time period. Edzna is one of the most extensively mapped cities in the state of Campeche. Its proximity to the coast, early discovery (1927), and deforestation by an agricultural project (1972) resulted in a substantial body of information on its cultural history and development, including a rare, well-understood urban hinterland. The Edzna Valley parallels the coast about $50 \mathrm{~km}$ inland and is only about $59 \mathrm{~m}$ above sea level. For a city, Edzna is in a hydrologically precarious location near the head of the valley. Without a river and a substantial watershed, the ancient Maya needed to establish a reliable water supply to sustain a significant population aggregate. The Middle Preclassic (1000-400 B.c.) pioneers in the valley simply took advantage of the clay-lined floor of the valley and its water-retention capabilities to enjoy life around natural pools (aguadas). During the Late Preclassic period (400 B.C.-A.D. 250), however, an additional population element arrived who had a knack for hydrological engineering. They took advantage of the clay-lined valley to construct a dozen canals radiating from the central ceremonial plaza. The canals would have captured $88 \%$ of the rainfall in the valley and surrounding valley walls. The canals may have been intended initially to drain the valley for agricultural purposes, but they were ultimately used for water storage, as well. A system of reservoirs was constructed near large building complexes, and a low-gradient, shallow spillway canal drained excess water without depleting the water storage. The Edzna canals discovered by George Andrews are one of the largest public works in Mesoamerica. Ray Matheny and colleagues (1983), who recorded this system through aerial photography in the wet season, conducted dry-season measurements of evaporation and found very substantial differences in evaporation depending on vegetation cover. The landscape reconstruction of Edzna that one envisions is that the Maya probably stored water in linear features lined with large protective trees, and water lilies protected the surface. Matheny believes that canoes were probably used to traverse the city with trade and social networks.

The city of Calakmul presents a startling contrast to Edzna. Although a subject of study only since 1982 (Folan et al. 1995), $30 \mathrm{~km}^{2}$ of the city have been mapped, and room-by-room excavations have been conducted in the ceremonial center (Domínguez 1994; Domínguez et al. 1998; Folan, Gunn, and Domínguez 2001; Folan, Fletcher, May Hau, and Florey Folan 2001). It is located in the next higher basin from the Edzna Valley, 100-200 km from the coast at about $250 \mathrm{~m}$ above sea level. Calakmul is perched on a ridge that transverses the basin at about $45^{\circ}$ (Figure 3 ). The ceremonial center overlooks the El Laberinto bajo to the south and west, but the city extends about a dozen kilometers to the northeast into the headwaters of the El Ramonal bajo. Although $30 \mathrm{~km}^{2}$ of the city have been mapped, it may be as large as $70 \mathrm{~km}^{2}$ (Folan et al. 1995). The floor of the El Laberinto bajo was occupied after A.D. 200, apparently when the bajo waters were at dependably low levels because of an extended drought (Folan 1981; Gunn and Adams 1981; Gunn et al. 1994, 1995; Hodell et al. 1995). Stone platforms and stone-rimmed, elevated fields suggest that it was used for agricultural production, and stone-rimmed and 


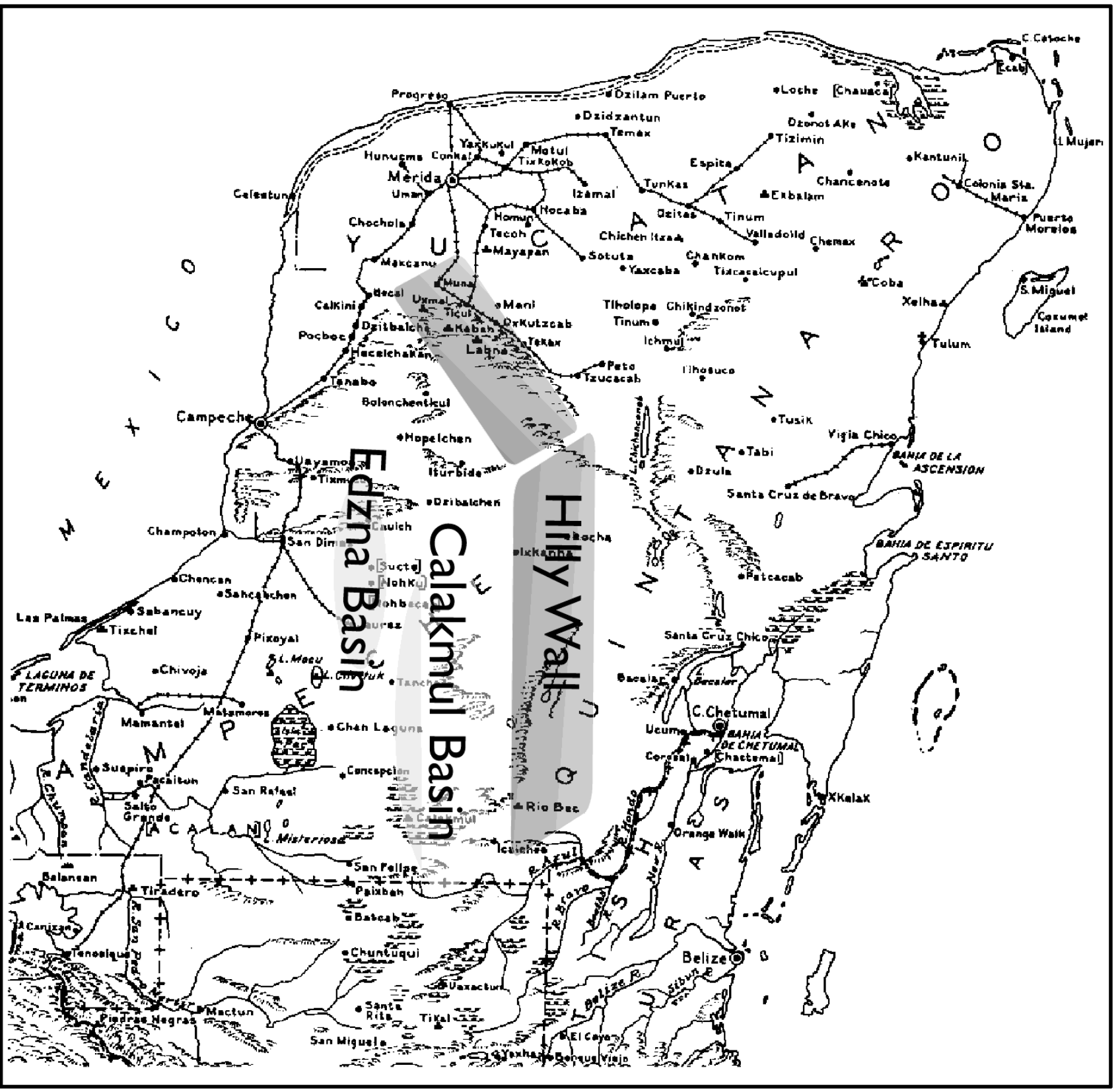

Figure 1. The Yucatan Peninsula showing the Edzna and Calakmul Basins and the Hilly Wall of Campeche.

lined reservoirs raised above the level of the bajo bottom mark water storage. In a study of the reservoir capacity of the city, Domínguez and Folan (1996) found that in the mapped area, aguadas were maintained both in the bajo and within the city away from the bajo. A modified arroyo near the ceremonial center channeled water through a canal to the primary bajo edge reservoir, which is $250 \mathrm{~m}$ on a side.

Surprising contrasts arise when the storage capacity of Edzna and Calakmul are compared (Table 1). Edzna is a city of only about $17 \mathrm{~km}^{2}$, but its identified water-storage capacity is more than 2 million $\mathrm{m}^{3}$. Matheny believes this is probably the greater share of the Edzna capacity. Given the benefits of clay for storage and the basin-bottom location of Edzna, it would not be surprising to find that it was "over-watered" in the sense that reservoirs were built beyond normal needs. (It has been suggested that the canal and reservoirs could also have been used for raising fish.) However, the conservatively identified water storage of Calakmul, which is about four times larger in urban footprint, is only about $228,000 \mathrm{~m}^{3}$, or about one-ninth that of Edzna. By any measure, the identified water supply of huge Calakmul is dwarfed by that of Edzna. If the identified storage is normalized to mapped square kilometers, Edzna possess more than seventeen times the storage of Calakmul per square kilometer. Another city of comparison is that of Tikal, where water storage has been mapped in the central 


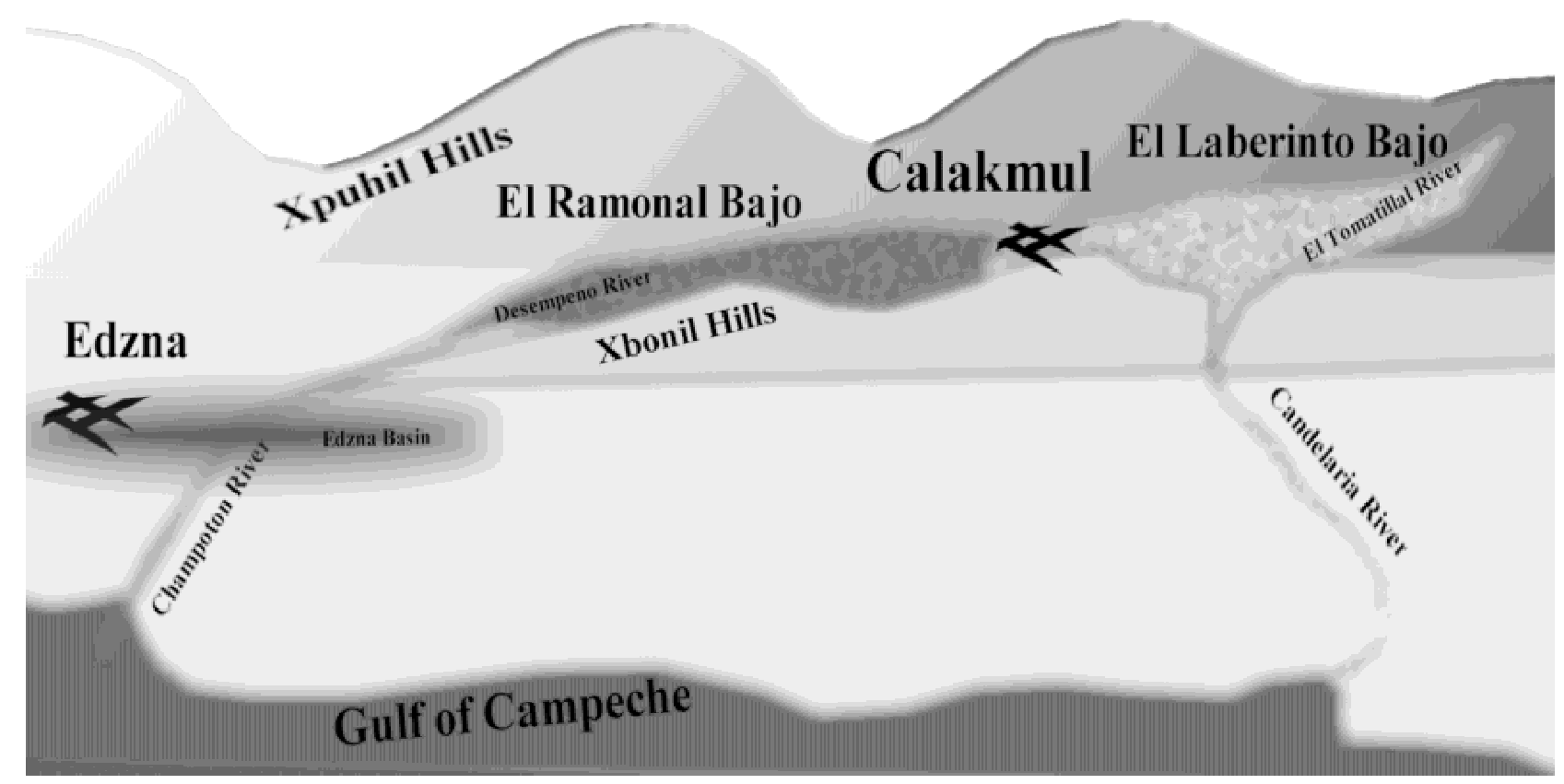

Figure 2. Campeche perspective map.

$9 \mathrm{~km}^{2}$ of the city (Scarborough 1998; Scarborough and Gallopin 1991). About three times as much storage has been identified conservatively per square kilometer in Tikal as Calakmul, while the higher "projected volume" suggests as much as eight times. (The storage capacities of Calakmul and Tikal still need to be finalized. A panel of interested scholars needs to be assembled to standardize estimation methods, because only three of what are identified as Tikal's aguadas now hold water; Peter Harrison, personal communication 2000).

A number of explanations for this divergence of storage capacity might apply, either singularly or in combination. First, and most likely, unidentified storage capacity exists in Calakmul; this might include reservoirs or cisterns (chultuns). Second, the population densities at Calakmul and Tikal might have been under- or overestimated. Third, special measures were used to limit per capita water consumption. A thorough understanding of the problem would require exploring all of these alternatives. Similarly, the population of the Edzna Valley may have been seriously underestimated.

\section{BAJOS AND WATER SUPPLY}

The current study sponsored by the National Geographic Society and the Universidad Autónoma de Campeche, Centro de Investigaciones Históricas y Sociales (CIHS), is primarily concerned with the function of the bajo in the Calakmul hydrological system. We will return to the off-bajo components of that system later. The study of the bajo was undertaken by mapping in the bajo edge below the city, excavating units in the bajo to observe stratigraphy, and by coring more distant parts of the bajos for geochemical characteristics.
Mapping

The mapping of the bajo (May Hau 2001), as discussed earlier, showed raised fields and raised reservoirs. A satellite image of the El Laberinto bajo, in fact, shows a line of reservoirs along its 30-km length, suggesting that it was an important component of the hydrological system for Calakmul and other inhabited areas along the transverse ridge. Whether the water in the reservoirs was used for human consumption or horticulture is not known, but it is an important question. Certainly, pot irrigation would have been possible in raised fields that have been discovered lined with rocks along the bajo edge. Carrying water to the elevated bluffs above the bajo for irrigation and/or human consumption is something that needs to be studied in terms of the time and energy involved. Richard Hansen (1998; see also Jacob 1995) and his fellow researchers have found evidence for the carrying of organic soil and, by implication, water into the city of Nakbe for horticultural use.

\section{Excavation Units}

Excavations were conducted in the Laberinto Bajo within the mapped area (Table 2). The upper levels were coarse-grained. Perhaps they were deposited in a high-energy water environment as colluvium. The lower Preclassic strata contained high levels of salt that would have been deleterious for most types of vegetation. These strata are also extremely rich in potassium. Radiocarbon dates were obtained indicating that the bajo was occupied during the Early Classic period (A.D. 300) and later, but not during the earlier early Late Preclassic (400 B.C.) period (Domínguez 1993). 


\section{Calakmul}
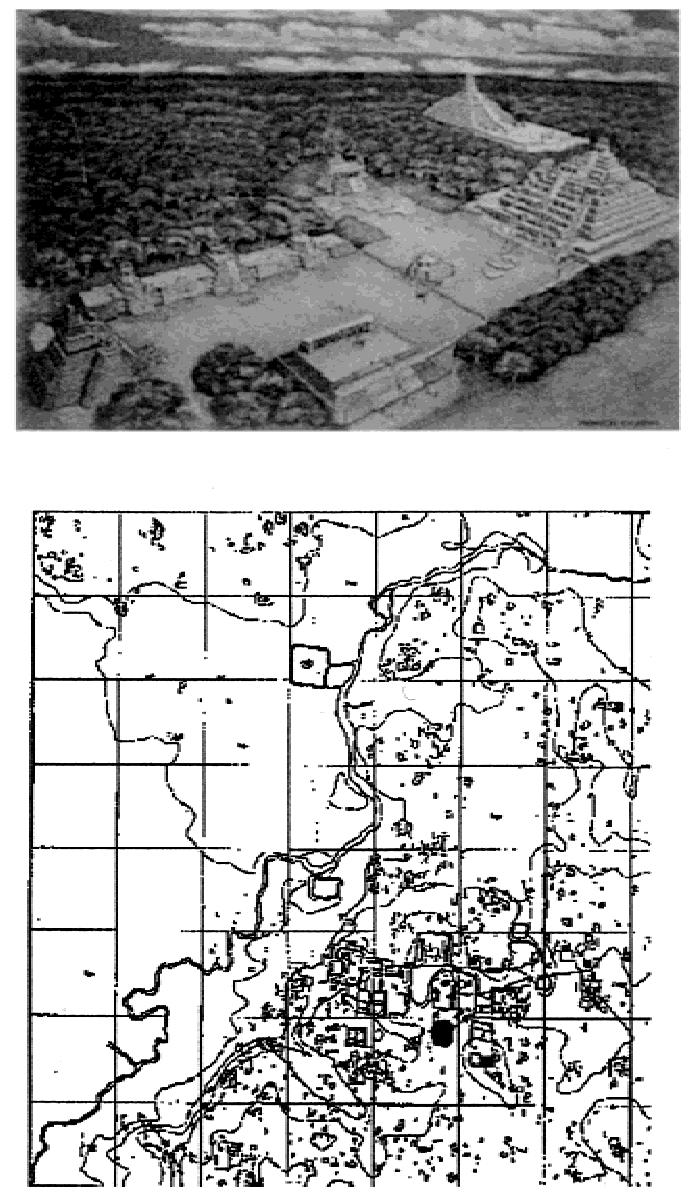

\section{Edzna}
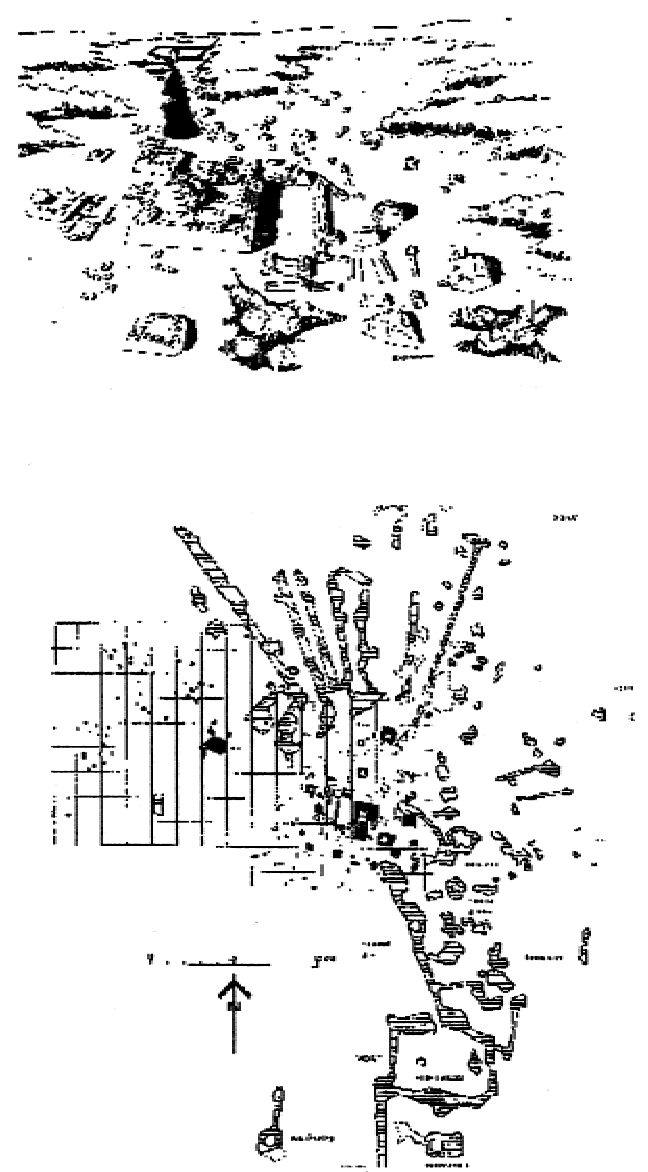

Figure 3. Comparison of Calakmul with Edzna; maps and reconstructions.

Distant Tests

Five different locations were cored near the edge $(\mathrm{N}=3)$ and in the centers $(\mathrm{N}=2)$ of the El Laberinto and El Ramonal bajos (Figure 4). Geochemical analyses from these cores (see later) indicated that the bajo center cores were highly saline and contained elevated proportions of gypsum; local custom holds that water containing gypsum is undrinkable, and if it contains saline it is also unfit for irrigation. Cores near the edges were less saline and contained elevated levels of calcium from nearby uplands and barium, indicating inclusion of plant material (for a discussion of gypsum/sodium and calcium in high water-table environments, see Pohl and Bloom 1996; for gypsum in lake environments, see Covich and Struiver [1974] and Leyden et al. [1994]). Phytolith assemblages were generally impoverished in the extreme and may reflect removal of upper-level soils for agriculture within nearby habitation areas. Drawing this evidence together, the elevated levels of salinity in the lower strata of the excavation units, and

Table 1. Identified water storage at mapped areas of selected Maya Lowland cities

\begin{tabular}{llll}
\hline \hline City & $\begin{array}{c}\text { Identified } \\
\text { Storage }\end{array}$ & Storage/km² & \multicolumn{1}{c}{ Source } \\
\hline Tikal projected $\left(\right.$ central $\left.9 \mathrm{~km}^{2}\right)$ & $567,604 \mathrm{~m}^{3}$ & $63,067 \mathrm{~m}^{3}$ & Scarborough and Gallopin (1991:61) \\
Tikal conservative $\left(\right.$ central $\left.9 \mathrm{~km}^{2}\right)$ & $206,742 \mathrm{~m}^{3}$ & $22,971 \mathrm{~m}^{3}$ & Scarborough and Gallopin (1991:61) \\
Edzna $\left(17 \mathrm{~km}^{2}\right)$ & $2,224,636 \mathrm{~m}^{3}$ & $1,307,332 \mathrm{~m}^{3}$ & Matheny et al. (1983:80) \\
Calakmul conservative $\left(\right.$ central $\left.30 \mathrm{~km}^{2}\right)$ & $228,150 \mathrm{~m}^{3}$ & $6,519 \mathrm{~m}^{3}$ & Domínguez and Folan (1996:190) \\
& & & \\
\hline \hline
\end{tabular}


Table 2. Excavation Unit 13(P)D units

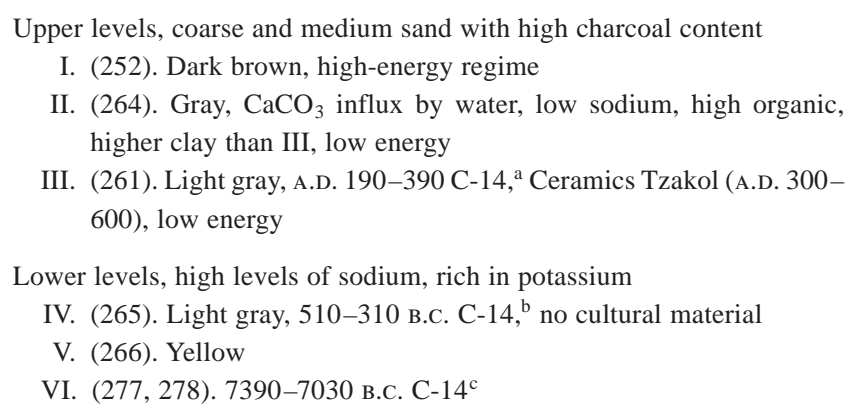

${ }^{\mathrm{a}} 1660 \pm 100$ в.P. Beta-50062, A.D. 410 calibrated, on sediment.

b $2360 \pm 100$ B.P. Beta 50063, 400 B.c. calibrated, on sediment.

${ }^{c} 9160 \pm 180$ в.P. Beta 50064,8090 в.C. calibrated, on sediment.

similar core findings near the centers of bajos, probably indicate that the bajos in their entirety were relatively saline under preurban conditions, at least seasonally. The bajos probably further increased in salinity as urbanization continued, because (1) clearing vegetation in the central bajo would have increased evaporation, which brings salts to the surface; and (2) increased runoff from uplands would have resulted in more salts being forced to the surface from the underlying high-salt strata by capillary action.

The excavation radiocarbon dates from Calakmul and absence of artifacts in the test units indicate that humans did not occupy the bajo in the early period of urbanization, which includes the early Late Preclassic period. However, use of the bajo edge began during the droughty conditions of the third century A.D. (the late Late Preclassic; see Dahlin et al. 1980; Gunn et al. 1994, 1995), when high-calcium material was released from the uplands into the edge of the bajo because of horticulture activities (Figure 5). The salinity of the lower strata of the Laberinto Bajo below Calakmul probably explains both elevated fields and elevated water supplies. Water would not be potable or useful for irrigation if it came into contact with the salinized lower strata. The high salt content of the interior part of the basins would result in persistent poor water quality there. The upper strata of the edge, however, with their high calcium systems and relatively low salt content (unless they were dug too deeply) would be excellent for potablewater storage and provide good water quality for human consumption and horticulture.

Radiocarbon dates and oxidizable carbon ratio (OCR) dates from the distant tests suggest that in at least one place, the city of El Laberinto, anthropogenic modification of the bajo edge sediments began earlier, during the Late Preclassic. Bajo sediments as they currently exist did not begin to accumulate until the Middle or Late Holocene (about 5,000 years ago). Greater precipitation during the Early and Middle Holocene probably scoured out preexisting sediments, if they were there before.

\section{CONCERNING NON-BAJO-EDGE WATER SUPPLIES}

As mentioned earlier, lesser reservoirs are scattered across Calakmul. The answer to the question of how to design a sprawling city such as Calakmul socially and hydrologically in an interior environment without existing permanent water supplies may lie as near as the modern Maya village of Pich. During the summer of 1999 the senior (Joel Gunn) and junior (Betty Faust) authors spent a month in the Maya village of Pich. Pich is located east of Edzna in the hills between the Edzna and the Calakmul basins. The environment is more similar to Calakmul because of its ridge-top location. A now dismantled pre-Hispanic temple once overlooked the narrows of a stream at the foot of an upland valley, effectively an arroyo. Below the village, the arroyo descends into the Edzna Valley. Within the village, a reservoir was maintained from ancient times until 1968, when the federal government dug a well (Faust 1998; Faust and Morales López 1993). Before the well, families rotated responsibility to provide one man to insure that the streets were kept clean for water collected in the village during rains. A stone wall was maintained to restrain animals and children from entering the reservoir. Social obligations of the village evolved around rewards and penalties for participating in the annual cleaning of the reservoir and the canal leading to it. A stand of high forest in the valley above Pich filtered the water entering through the canal from the surrounding hills.

Given the contrasts between Edzna and Calakmul outlined earlier, the social organization of Pich may reveal the secret of Calakmul's great size. It is clear from the intricate interweaving of canals and building complexes at Edzna that the city possessed a central planning department that maintained authority over a long period of time. To be sure, Calakmul has monumental architecture. The centerpiece of the ceremonial district is Temple Structure II (height: $55 \mathrm{~m}$ ), which is twice the height of the Cinco Pisos structure at Edzna (height: $28 \mathrm{~m}$ ), and whose footprint is nearly equal to the whole of the acropolis at Edzna (Figure 2). However, no overall plan has emerged at Calakmul comparable to all of the canals oriented on the Cinco Pisos temple. Calakmul is so vast, capping many hills, that such a plan seems unlikely. However, the scattered reservoirs may hold the key to understanding Calakmul's urban structure. The ceremonial plaza is located in the west edge of the city overlooking the largest reservoirs and fields in the bajo below as at many other Maya cities (Scarborough 1998). The rest of the city spreads across the hills to the east toward the El Ramonal bajo. Obviously, the governors of the central plaza drew on this sprawling population to construct imposing monuments. However, one can imagine that, rather than coming under a central planning authority that constructed one unified water system, Calakmul was also organized around a number of reservoir-centered barrios. Each barrio would have been a Pich-like module within the overall Calakmul system. It would have maintained its own central reservoir, probably surrounded by imposing trees that sheltered the reservoir from excessive evaporation while fed by runoff from house tops, patios, lesser ceremonial centers, and streets maintained to capture precipitation. Such a system would have been infinitely extensible, given adequate rainfall and sufficient food, while salt and other goods could be imported from the hinterlands to maintain the inhabitants. Test implications would include catchments between reservoirs proportional to housing.

\section{FIELD DATA COLLECTION AND ANALYSIS}

Here we discuss the collection of auger samples for distant (from Calakmul) tests and their analysis. The samples were collected during the Campeche Interior Basin Pedology Study, which was sponsored by the National Geographic Society, and executed under the co-sponsorship of the CIHS, directed by William J. Folan. Folan was in charge of the project. John E. Foss was the pedolo- 


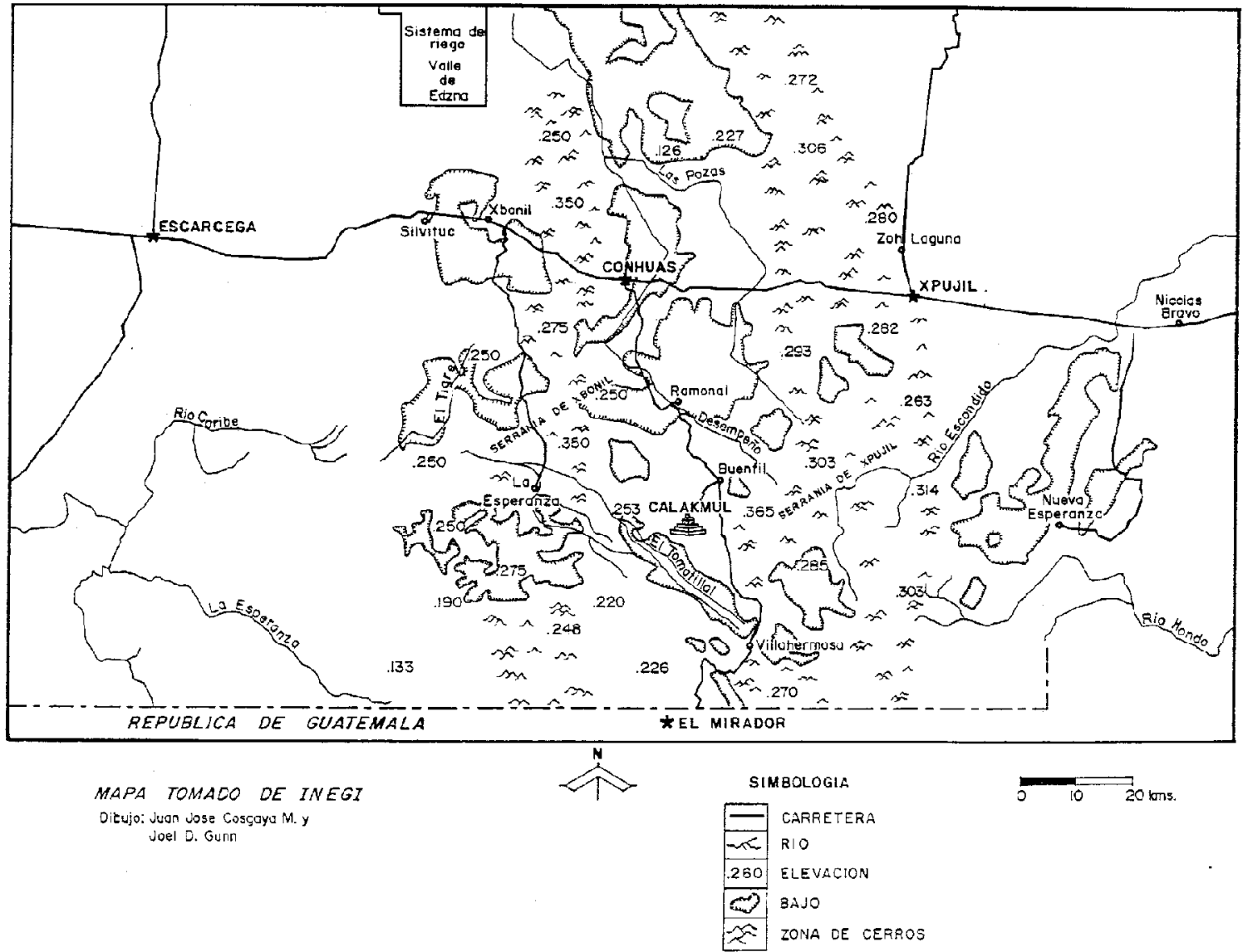

Figure 4. Map of the Calakmul Basin. The southern extreme of the Edzna Basin is visible in the upper right.

gist; he directed the placement of cores and location of sample locations. He also provided the soil descriptions and guided analysis. Gunn acted as project recorder, keeping a running log of the project and recording the insights and observations of project members in the field and during subsequent laboratory work. Gunn was primarily responsible for writing the report. The cores were taken during fieldwork on 7-9 April 1999.

Two seasonal swamps were visited (Table 3). Three different parts of the El Laberinto bajo were tested (Figure 4)-one near Villahermosa, a location referred to locally as the Hulubal bajo; a tributary bajo to the El Laberinto bajo; and the El Laberinto bajo below the archaeological site of El Laberinto. The El Laberinto bajo watershed exits the Calakmul Basin near the former ejido of Concepcion into the Gulf of Campeche coastal plain in the Candelaria River system. See Gunn and colleagues $(1994,1995)$ for a complete description of the Candelaria watershed and the climatology of the Calakmul Biosphere Reserve (Folan et al. 1992). All three locations were within a few meters of where the bajo was crossed by the Conhuas-Villahermosa road.

The second location was in the El Ramonal bajo where it was crossed by the Conhuas-to-Calakmul road. The El Ramonal bajo empties into the Desempeño River, which flows northwestward through the Calakmul Basin and through a labyrinth of swamps joins the Champoton River near Edzna.

The physiographic and cultural context of the cores was an important part of their location strategy. The El Laberinto and
Hulubal cores were from the El Laberinto bajo, which the city of Calakmul overlooks, near where its water flows through a gap in the Xbonil Hills and into the coastal plain toward the town of Candelaria, Campeche. The El Ramonal cores are from the El Ramonal bajo near the El Ramonal archaeological site. The El Ramonal bajo is a tributary of the Desempeño-Champoton River system, which exits the Calakmul Basin near Edzna. Both core series were located near the headwaters of their respective bajoriver systems. Except for the Hulubal core, cores were taken in pairs in the center and near the edge to observe the stratigraphic and temporal duration and resolution of the sediments in those sedimentary environments. The Hulubal core was near an aguada at the edge of an extension of the El Laberinto bajo. Guides familiar with modern agricultural practices in the area reported that this place was always moist and a likely spot for important milpas (Carmen Pech Garcia, personal communication 1999).

\section{ANALYSIS OF CORE SAMPLES}

Forty-one auger samples were taken from the bajos. They were recovered with a 5-inch bucket auger, and soils descriptions were performed immediately. Samples were taken from each bucket load, and the depth of the hole was recorded. In the laboratory in Campeche, the samples were air-dried and divided into subsamples for transportation to inductively coupled plasma (ICP), OCR, 


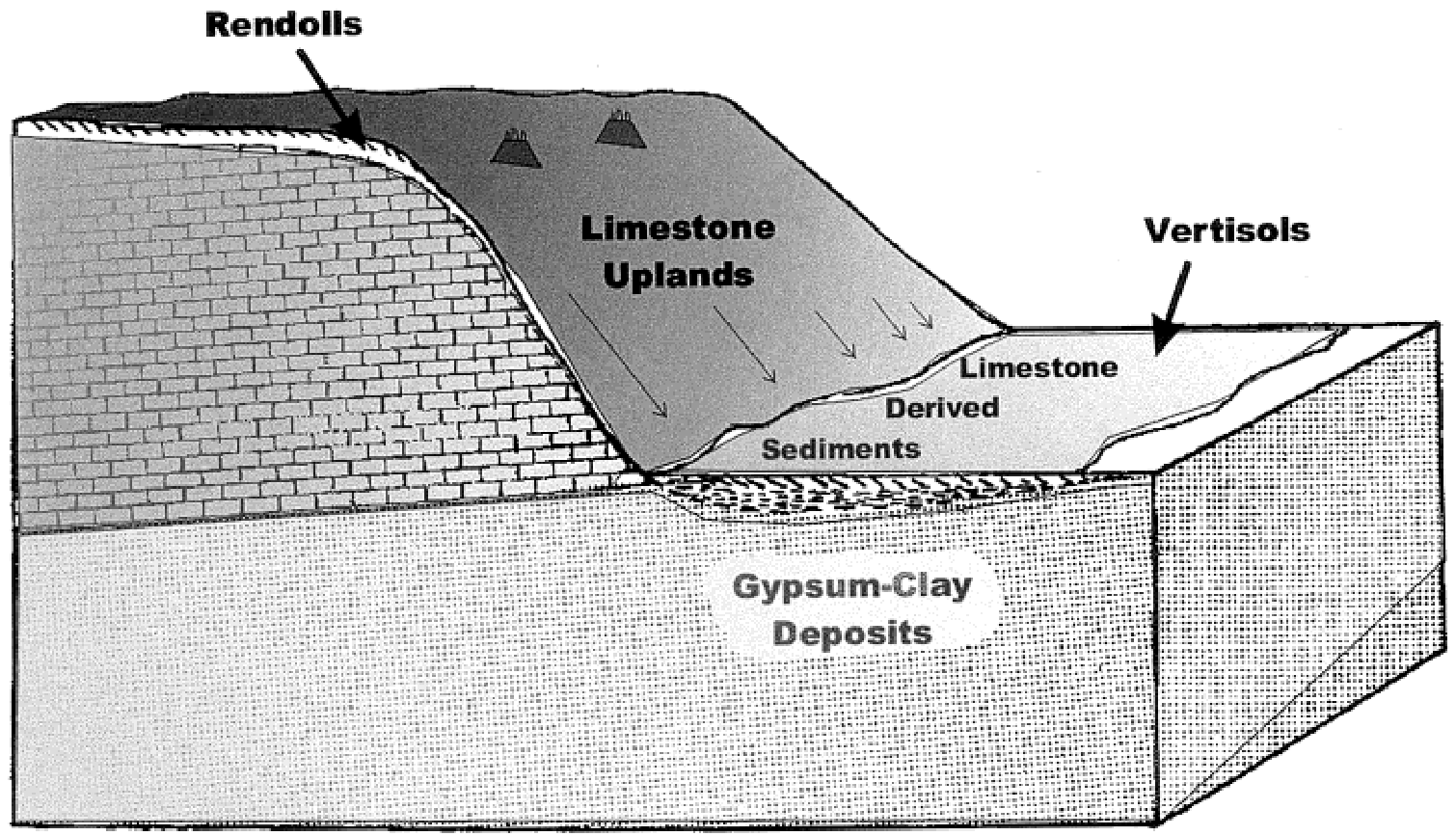

Figure 5. Idealized landscape profile in the Calakmul Basin.

and phytolith facilities. Radiocarbon dates (AMS) were taken from the phytolith subsamples.

\section{SOILS DESCRIPTIONS}

The soils of the bajo bottom cores were described using U.S. Department of Agriculture National Resources Conservation Service standards (Table 4). They were predictably Vertisols, as is typical of many accumulated sediments in limestone terrain. Although there are similarities between the two bajos, notable variations clearly emerged.

1. Major difference between bajo center and edge is generally due to the large quantity of gypsum in the $\mathrm{C}$ horizon $(\mathrm{Cy})$ present near the center and almost complete lack of gypsum in the $\mathrm{C}$ horizon on the edges. Cy strata contain soluble gypsum, and Ck contains less soluble calcium carbonate. Bajo edges increasingly form calcium carbonate systems as compared with the centers.

2. All of the observed mottles are in the El Laberinto bajo; there are none in the El Ramonal bajo.

3. Although slickensides (Bss) soil structures occur in El Ramonal only at one location, they are clearly characteristic of the El Laberinto bajo.

Vertisols are sometimes called "self-swallowing" because montmorillenitic clay constitutes about $80 \%$ of the clay fraction, causing a large shrink-swell characteristic. If extreme drying and cracking occurs, upper (usually darker) sediments drop into lower strata, resulting in a gross overturning of stratigraphy over time. Of course, the rate of overturning is highly variable, depending on the depth and frequency of drying and on the clay content. Whether

Table 3. Cores taken in the Calakmul Basin

\begin{tabular}{|c|c|c|}
\hline Location & $\begin{array}{l}\text { Samples/ } \\
\text { Maximum Depth }\end{array}$ & Description (all locations are near the Conhuas roads to Villahermosa and Calakmul) \\
\hline El Laberinto 1 (center) & $8 / 170 \mathrm{~cm}$ & $\begin{array}{l}\text { In the center of the El Laberinto bajo near Villahermosa, Campeche; it was not near } \\
\text { the El Tomatillal stream at the core of the bajo }\end{array}$ \\
\hline El Laberinto 2 (edge) & $7 / 200 \mathrm{~cm}$ & $\begin{array}{l}\text { At the edge of the El Laberinto bajo overlooked by the ruin of El Laberinto; it was } \\
\text { in the scree fan at the edge of the bajo }\end{array}$ \\
\hline Hulubal (edge) & $8 / 150 \mathrm{~cm}$ & $\begin{array}{l}\text { Near an aguada in a side bajo of the El Laberinto bajo; it was probably not in the scree } \\
\text { fan; the Hulubal bajo may be lower in elevation than the general El Laberinto bajo }\end{array}$ \\
\hline El Ramonal 1 (edge) & $8 / 155 \mathrm{~cm}$ & $\begin{array}{l}\text { At the edge of the El Ramonal bajo near the ruin of El Ramonal; this was probably } \\
\text { in the scree fan at the edge of the bajo }\end{array}$ \\
\hline El Ramonal 2 (center) & $10 / 205 \mathrm{~cm}$ & $\begin{array}{l}\text { In the center of the El Ramonal bajo; there was evidence of broad water flow } \\
\text { (sheetwash) toward the Desempeño River in the vicinity of the core; a stream } \\
\text { through the core of the bajo was about } 300 \mathrm{~m} \text { to the north }\end{array}$ \\
\hline
\end{tabular}


Table 4. Description of soils and samples in the Campeche Interior Basin Project, El Laberinto bajo and El Ramonal bajo, April 1999

\begin{tabular}{|c|c|c|c|c|c|c|c|c|c|}
\hline Horizon & Depth & Color & Mottles & Text & Structure & Consistency & Bound & Gypsum & $\mathrm{CO}_{3}$ \\
\hline \multicolumn{10}{|c|}{ El Laberinto bajo } \\
\hline \multicolumn{10}{|c|}{ S99MS2 El Laberinto bajo 1, center $^{\mathrm{a}}$} \\
\hline A & $0-10$ & 10YR 3/1 & None & $\mathrm{C}$ & - & Vfi & Cs & 0 & 0 \\
\hline $\mathrm{AB}$ & $10-30$ & 10YR 4/1 & None & $\mathrm{C}$ & - & Vfi & $\mathrm{Cs}$ & 0 & 0 \\
\hline Bss 1 & $30-50$ & $\mathrm{G} 0 / 5$ & None & $\mathrm{C}$ & - & Vfi & Gs & 0 & 0 \\
\hline Bss2 & $50-75$ & G $0 / 5$ & None & $\mathrm{C}$ & - & Vfi & Gs & 0 & 0 \\
\hline Bss3 & $75-90$ & $2.5 \mathrm{Y} 6 / 1,4 / 1$ & None & $\mathrm{C}$ & - & Vfi & - & 1 & 0 \\
\hline Bss4 & $90-120$ & $2.5 \mathrm{Y} 6 / 2,4 / 1(20 \%)$ & None & $\mathrm{C}$ & - & Vfi & - & 1 & 0 \\
\hline Cy 1 & $120-140$ & $2.5 Y 8 / 1,5 / 2(20 \%)$ & C2d 10YR 5/6 & $\mathrm{Sc}$ & - & $\mathrm{Fr}$ & - & 4 & 1 \\
\hline Cy2 & $140-170$ & $2.5 Y 8 / 2$ & M2d $2.5 Y 6 / 3$ & $\mathrm{Sc}$ & - & $\mathrm{Fr}$ & - & 4 & 1 \\
\hline Сy3 & $170-222$ & $2.5 \mathrm{Y} 6 / 1$ & - & $\mathrm{Sc}$ & - & - & - & 4 & - \\
\hline Cy4 & $222-300$ & $2.5 \mathrm{Y} 7 / 2$ & - & $\mathrm{Sc}$ & - & - & - & 4 & - \\
\hline \multicolumn{10}{|c|}{ S99MX4 Bajo Hulubal edge ${ }^{b}$} \\
\hline A & $0-10$ & 10YR 2/1 & None & $\mathrm{C}$ & $3 \mathrm{mgr}$ & Vfi & $\mathrm{Cs}$ & 0 & 2 \\
\hline $\mathrm{AB}$ & $10-25$ & 10YR 4/1 & None & $\mathrm{C}$ & - & Vfi & Cs & 0 & 2 \\
\hline Bss 1 & $25-60$ & 10YR 4/1 & None & $\mathrm{C}$ & - & Vfi & Gs & 0 & 2 \\
\hline Bss2 & $60-70$ & $2.5 Y 5 / 1$ & None & $\mathrm{C}$ & - & Vfi & Gs & 0 & 2 \\
\hline Bssk1 & $70-100$ & $2.5 \mathrm{Y} 5 / 1$ & None & $\mathrm{C}$ & - & Vfi & Gs & 0 & 3 \\
\hline Bssk2 & $100-130$ & $2.5 \mathrm{Y} 5 / 1$ 10YR 4/1 & None & $\mathrm{C}$ & - & Vfi & Gs & 0 & 3 \\
\hline BCk1 & $130-150$ & $2.5 \mathrm{Y} 6 / 1$ & None & $\mathrm{C}$ & - & Vfi & Gs & 0 & 3 \\
\hline $\mathrm{BCk} 2$ & $150-200$ & $2.5 \mathrm{Y} 6 / 1$ & Mlf $2.5 Y$ 6/4 & $\mathrm{C}$ & - & - & - & 0 & 3 \\
\hline $\mathrm{C} / \mathrm{Ak}$ & $200-240$ & 2.5 Y 6/2 10YR 3/1 (15\%) & - & $\mathrm{C}$ & - & - & - & 0 & 4 \\
\hline $\mathrm{C}$ & $240-300$ & $2.5 \mathrm{Y} 6 / 1$ & - & $\mathrm{C}$ & - & - & - & 0 & 4 \\
\hline \multicolumn{10}{|c|}{ S99MX6 El Laberinto bajo 2, edge ${ }^{\mathrm{c}}$} \\
\hline A & $0-10$ & 10YR 3/1 & None & $\mathrm{C}$ & $2 \mathrm{mgr}$ & Vfi & $\mathrm{Cs}$ & 0 & 1 \\
\hline $\mathrm{AB}$ & $10-30$ & $10 Y R 4 / 1,5 / 1$ & None & $\mathrm{C}$ & - & Vfi & $\mathrm{Cs}$ & 0 & 1 \\
\hline Bss & $30-75$ & 10YR $5 / 1$ & None & $\mathrm{C}$ & - & Vfi & Gs & 0 & 3 \\
\hline Bss/Ab? & $75-90$ & 10 YR 5/1 & None & $\mathrm{C}$ & - & Vfi & Gs & 0 & 4 \\
\hline Bssk1 & $90-110$ & 10YR 5/1, 4/1 & None & $\mathrm{C}$ & - & Vfi & Gs & 0 & 4 \\
\hline Bssk2 & $110-130$ & 10YR 4/1 & None & $\mathrm{C}$ & - & Vfi & Gs & 0 & 4 \\
\hline $\mathrm{BCk}$ & $130-150$ & 10YR 4/1 & None & $\mathrm{C}$ & - & Vfi & Gs & 0 & 4 \\
\hline Ck1 & $150-240$ & $2.5 \mathrm{Y} 4 / 1,2.5 \mathrm{Y} 6 / 2(10 \%)$ & None & $\mathrm{C}$ & - & Vfi & Gs & 0 & 4 \\
\hline Ck2 & $240-300$ & $2.5 \mathrm{Y} 6 / 2$ & None & $\mathrm{C}$ & - & Vfi & - & 0 & 4 \\
\hline
\end{tabular}

El Ramonal bajo

\begin{tabular}{|c|c|c|c|c|c|c|c|c|c|}
\hline \multicolumn{9}{|c|}{ S99MX8 El Ramonal bajo 1, edge ${ }^{\mathrm{d}}$} & \\
\hline A & $0-15$ & $10 \mathrm{YR} 3 / 1$ & None & $\mathrm{C}$ & $2 \mathrm{mgr}$ & Vfi & Cs & 0 & 2 \\
\hline $\mathrm{AB}$ & $15-30$ & 10YR 4/1 & None & $\mathrm{C}$ & - & Vfi & Gs & 0 & 2 \\
\hline $\mathrm{Bg}$ & $30-70$ & 10YR 5/1 & None & $\mathrm{C}$ & - & Vfi & Gs & 0 & 2 \\
\hline BCgk1 & $70-90$ & 10YR 6/1 & None & $\mathrm{C}$ & - & Vfi & Gs & 0 & 3 \\
\hline Bcgky & $90-105$ & 10YR $6 / 2$ & None & $\mathrm{C}$ & - & Vfi & Gs & 2 & 3 \\
\hline Bcgky & $105-140$ & 10YR $6 / 2$ & None & $\mathrm{C}$ & - & Vfi & Gs & 2 & 3 \\
\hline Cgy1 & $140-155$ & 10YR 9/1 & None & $\mathrm{C}$ & - & $\mathrm{Fr}$ & - & 4 & 1 \\
\hline Cgy2 & $155-240$ & 10YR 6/2 & None & $\mathrm{C}$ & - & - & - & 4 & 1 \\
\hline \multicolumn{10}{|c|}{ S99MX10 El Ramonal Bajo 2, center ${ }^{\mathrm{e}}$} \\
\hline A & $0-10$ & $10 Y R 3 / 3$ & None & $\mathrm{C}$ & $3 \mathrm{mgr}$ & Vfi & $\mathrm{Cs}$ & 0 & 1 \\
\hline $\mathrm{AB}$ & $10-25$ & 10YR 4/1 3/3 (20\%) & None & $\mathrm{C}$ & - & Vfi & Cs & 0 & 1 \\
\hline Bss1 & $25-40$ & 10YR 5/1 & None & $\mathrm{C}$ & - & Vfi & Gs & 0 & 1 \\
\hline Bss2 & $40-65$ & $2.5 Y 5 / 1$ & None & $\mathrm{C}$ & - & Vfi & Gs & 0 & 1 \\
\hline $\mathrm{BC}$ & $65-85$ & $2.5 \mathrm{Y} 5 / 1,6 / 2$ & None & $\mathrm{C}$ & - & Vfi & As & 0 & 1 \\
\hline 2A/B? & $85-100$ & $2.5 \mathrm{Y} 7 / 1,7 / 210 \mathrm{YR} 3 / 1$ & None & $\mathrm{C}$ & - & Vfi & Cs & 2 & 1 \\
\hline $2 / B$ & $100-120$ & $2.5 \mathrm{Y} 7 / 2,10 \mathrm{YR} 3 / 2, \frac{3}{4}$ & None & $\mathrm{C}$ & - & Vfi & Gs & 2 & 1 \\
\hline $2 \mathrm{BCk}$ & $120-140$ & $2.5 Y 7 / 1,7 / 2$ & None & $\mathrm{C}$ & - & Vfi & Gs & 2 & 3 \\
\hline 2 Су1 & $140-175$ & $2.5 Y 7 / 2,6 / 2$ & None & $\mathrm{C}$ & - & Vfi & - & 3 & 2 \\
\hline $2 \mathrm{Cy} 2$ & $175-205$ & $2.5 Y 7 / 2,6 / 2$ & None & $\mathrm{C}$ & - & Vfi & - & 4 & 1 \\
\hline 3 Су3 & $205-300$ & $2.5 Y 7 / 1,7 / 2$ & None & $\mathrm{C}$ & - & Vfi & - & 4 & 2 \\
\hline
\end{tabular}

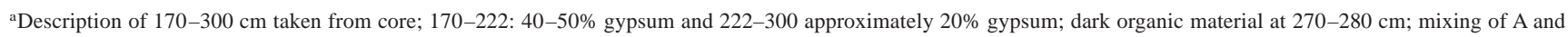
BC horizons at90-120 and A and Bss mixing at 75-90 cm; laboratory number: NGS99-01 to NGS99-008; center of bajo: describe and sampled 7 April 1999.

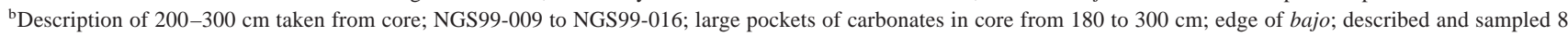
April 1999.

'Description of 150-300 cm taken from core; auger hit limestone block $150 \mathrm{~cm}$; edge of bajo; accumulation of $1 \mathrm{~cm}$ sized carbonate soft nodules 90-300 cm; laboratory numbers NGS99-017 to NGS99-023; described and sampled 8 April 1999.

${ }^{\mathrm{d}}$ Description of $155-240 \mathrm{~cm}$ taken from core; near edge of bajo; limestone encountered at $240 \mathrm{~cm}$; laboratory numbers NGS99-024 to NGS99-031; two samples in Bg30-50 and 50-70 cm; clusters of carbonates from 70-140, some 1-2 cm in diameter; described and sampled 9 April 1999.

${ }^{\text {e}}$ Description of 205-300 cm taken from core; large clusters of gypsum crystals from 240-300, with some crystals 1-2 cm in length; Mn-Fe concretions; NGS99-032 to NGS99-041; described and sampled 9 April 1999. 
these bajo sediments were significantly overturned is an important issue for this study, because the research design (Gunn et al. 2000) was intended to investigate the feasibility of studying bajo stratigraphy for signatures of past climates and anthropogenic effects. Obviously, if the swamps dominated the yearly cycle of moisture of the last millennia, maintaining moist, largely anaerobic subsurface conditions, we could expect to find signatures of such conditions intact. However, if the overturning was significant, we might expect any geochemical signatures we found to be indicative of other processes inherent to the vertic soils.

Some evidence of anaerobic conditions was observed microscopically during the OCR sediment examinations. This suggests that the enduring presence of water minimized the damage done to stratigraphic integrity. Gleyed $(\mathrm{Cg})$ strata were observed in the El Ramonal 1 Edge core, which also suggests anaerobic conditions. We see in the soils themselves evidence of minimal overturning, indicated by mostly light-color sediments in the lower strata. More dark material seems to have been introduced into lower strata in the El Laberinto bajo than in the El Ramonal bajo. This could, as in other analyses, reflect more human activity in the El Laberinto bajo (such as deforestation and therefore more exposure to evaporation and more shrink-swell action). Thus, in our judgment, both bajos experienced minimal overturning of sediments, with the majority of it occurring in the El Laberinto bajo.

\section{ICP, OCR, CARBON-14, AND PHYTOLITH ANALYSES}

Subsamples were analyzed by various means depending on time and the resources of the project. ICP and OCR determinations were made on all samples. Phytolith observations were made on thirteen selected samples because of greater cost. AMS dates were run on four samples. The methods chosen for the analysis were selected not only for their appropriateness to the research objectives but also for the richness of the auxiliary information they produce. The primary objective of the ICP analysis was to measure calcium and sulfur content. However, the ICP analysis was set to collect information on 26 elements reflecting a wide range of atomic weights and chemical characteristics. OCR determinations require the generation of grain size (seven classes), organic content, and $\mathrm{pH}$. These data provide objective measures of grainsize characteristics. The OCR analysis also included microscopic observations on the sediments that yielded information on volcanic particles in the strata and possible anaerobic conditions. Phytolith analysis amounts to something of an obverse of the OCR determinations - that is, a microscopic analysis of samples cleaned of non-biological (non-biogenic) and most carbonaceous sediment constituents.

All analyses except radiocarbon were conducted for $\$ 100$ a sample, or much less, allowing for the proliferation of data necessary to establish broad characterizations of the sediments. One of the underlying principles of the approach is to rely on the holistic and synergistic effects of many analyses to enhance the quality of key observations critical to the hypotheses being tested.

Among the synergy-producing effects are trends with depth and multiple views of the same phenomena. Multiple measures of the same phenomena can be detected by factor analysis, which reduces the complexity of the large number of measures to the simplest set of dimensions, or factors, possible. At the same time, it takes advantage of the multiple measures to establish quality of data through replication of measures.
We also expected previously unknown phenomena to correlate with known phenomena, providing clues to the origin and meaning of the unknown phenomena. This should expand our understanding of unknown phenomena through relationships to previously known phenomena.

\section{ICP Analysis}

ICP determinations were run on all 41 samples for 26 elements. Of these, six elements were below the level of determination in all samples, leaving 20 analyzable variables (Table 5). Although ICP analysis determines only the proportional elemental composition of a sample, relevant compounds generally can be inferred by considering the context. For example, sulfur in an ICP analysis for the bajos mostly represents the sulfur in dolomite. Similarly, sodium indicates the presence of salt. We also found that the relative weight of elements was important-that is, heavy metals as opposed to lighter elements such as sodium and potassium. Certainly, the solubility of lighter elements is important. Sodium and sulfur are very soluble, and therefore mobile, while calcium is less soluble and mobile.

Among the results evident in the ICP profiles of cores is clear evidence of down-core concentrations of heavy metals and sulfurcalcium (see the discussion of factor analysis later). Because heavy metals also occur in the surface strata, we assume that the downcore heavy metals were an indication of past, now buried, stable surfaces. Our best estimate is that such a stable surface should date to before human occupation affected the sediments during the Late Preclassic period (500 B.C.-A.D. 200), or earlier. As the sulfurcalcium strata are above the heavy metals, they could represent

Table 5. List of elements selected in the ICP analyses with detectable quantities

\begin{tabular}{|c|c|}
\hline Element & Utility \\
\hline $\begin{array}{l}\mathrm{PH} / \mathrm{H}_{2} \mathrm{O} \\
\text { Aluminum (Al) } \\
\text { Boron (B) }\end{array}$ & $4=$ very acid, $7=$ neutral, $9=$ very basic \\
\hline Barium (Ba) & $\begin{array}{l}\text { Accumulates from concentrated vegetation decay, } \\
\text { usually anthropogenic }\end{array}$ \\
\hline $\begin{array}{l}\text { Calcium }(\mathrm{Ca}) \\
\text { Cadmium }(\mathrm{Cd}) \\
\text { Cobalt }(\mathrm{Co}) \\
\text { Chromium }(\mathrm{Cr}) \\
\text { Copper }(\mathrm{Cu}) \\
\text { Iron }(\mathrm{Fe}) \\
\text { Potassium }(\mathrm{K}) \\
\text { Magnesium }(\mathrm{Mg}) \\
\text { Manganese }(\mathrm{Mn})\end{array}$ & Primarily indicator of limestone in this context \\
\hline Sodium (Na) & $\begin{array}{l}\text { Indicator of salt, highly mobile like sulfur in } \\
\text { gypsum (sulfur) }\end{array}$ \\
\hline $\begin{array}{l}\text { Nickel }(\mathrm{Ni}) \\
\text { Lead }(\mathrm{Pb})\end{array}$ & \\
\hline Sulfur (S) & $\begin{array}{l}\text { Primarily constituent of gypsum, mostly indicator of } \\
\text { gypsum in this context, highly mobile like sodium }\end{array}$ \\
\hline Silicon (Si) & \\
\hline Strontium (Sr) & $\begin{array}{l}\text { Proportional to sea level in marine contexts such } \\
\text { as shell }\end{array}$ \\
\hline Zinc $(\mathrm{Zn})$ & \\
\hline
\end{tabular}


Table 6. List of variables from the OCR analyses

\begin{tabular}{ll}
\hline Depth & \multicolumn{1}{c}{ Level Midpoint } \\
\hline OCRRatio & Oxidized carbon ratio \\
OCRDate & OCR date \\
PHOCR & pH: $4=$ very acid, $7=$ neutral, $9=$ very basic \\
\%OrgCar & Percentage organic carbon \\
Vcoarse & Very coarse sand \\
Coarse & Coarse sand \\
Med & Medium sand \\
Fine & Fine sand \\
Vfine & Very fine sand \\
Csilt & Coarse silt \\
Fsilt & Fine silt \\
\end{tabular}

slumped sediments from the surrounding uplands arriving during the Classic period (A.D. 200-800). This structure was used to inform the radiocarbon dating discussed later.

\section{OCR Analysis}

OCR determinations were made on 41 samples. This produced grain-size analysis (sand and silt) for each sample, along with measures of the percentage of organic carbon, and $\mathrm{pH}$ yielding nine analyzable variables (Table 6). Since the oxidation of carbon requires an aerobic environment, and the sediments of a seasonal swamp by nature are aerobic for only part of the year, the OCRdate determinations are considered to be experimental in nature. They were included in the analysis as much to obtain insights into the carbon-oxidation process in bajos as to acquire true dates. We found that the dates do produce profiles that age with depth. There were also age reversals in the profiles that suggest the presence of oxidation horizons, strata in the visually undifferentiated columns that were stable for long enough to rush the carbon-oxidation process. This was perhaps the most valuable outcome of the OCR analyses apart from the auxiliary data they supplied. Suggestions can be derived in contexts where OCR dates are paired with radiocarbon dates to correct the OCR dates taken from partially anaerobic circumstances.

\section{Radiocarbon Analysis}

Radiocarbon AMS dates were run on four samples (Table 7). The samples were dated to test the hypothesized ages of the heavy metal and sulfur-calcium horizons and to provide context for the experimental OCR dating. As there was no visual evidence of organic content in the samples, they were scanned by scanning electron microscope before processing to ensure the potential for dating. All four samples proved to have sufficient organic material for dating. None of the calibrations encountered multiple intercepts.

Criteria were imposed to inform the selection of dates in the horizontal and vertical dimensions. The vertical strategy was to run two dates from the El Laberinto 2 core to bracket the lower, presumably Preclassic, stable surface (heavy-metal horizon; Samples 020 and 021). The horizontal strategy was to date heavymetal and sulfur-calcium horizons in both bajos (Samples 012 and 036). In addition, two samples were chosen, even though chiton did not appear in the phytolith slides. This in effect tests whether the ash observed in the phytolith slides was a good indicator of the amount of carbon in the samples (Samples 021 and 036). Both samples provided good dates despite the absence of chiton.

El Laberinto 2 (edge, 75-90 cm), Sample 020. Sample 020 resided in the layer above the presumed Preclassic surface (heavy-metal horizon) and therefore could represent Classic-period slump from the nearby uplands. (This sample was judged by the phytolith analyst to have a medium concentration of ash or chiton.)

The calibrated date was 370 в.c. This indicates that the slumping began earlier at the city of El Laberinto than at Calakmul (see the earlier discussion of excavations at Calakmul). It would be more comparable to the age of the slumping reported by Hansen and colleagues at Nakbe (Hansen 1998).

El Laberinto 2 (edge, 90-110 cm), Sample 021. Sample 021 was selected because it was in the presumed Preclassic heavy-metal horizon. If the heavy-metal horizon represents a long-term stable surface, its date would be a mean residence time date. That is, it resembles an average of the time the horizon was a stable surface. If most slumping occurred during the Classic period, it should antedate A.D. 250. (No ash was observed in this sample's phytolith slide. It is a test for the presence of carbon in non-ash slides.)

The calibrated date was 780 B.C. It is early enough to represent an early stable surface.

El Ramonal (center, 65-85 cm), Sample 36. Grass phytoliths were present in the sample, suggesting an open-canopy biotic regime. Also, it is above the down-core, heavy-metal horizon. It could be correlated with Classic-period deforestation-thus, the open canopy. (No ash was observed in the phytolith slide for this sample, as was the case for all samples from the El Ramonal bajo. The date tests whether the non-ash samples can be dated.)

The calibrated date was A.D. 430, within the expected range of the Classic period.

Hulubal (edge, 60-70 cm), Sample 12. A liability came with this sample, as Hulubal was the only core without a down-core, heavy-

Table 7. Dates from the AMS radiocarbon analyses

\begin{tabular}{lccccc}
\hline \hline Beta no. & Location & Measured & C-13/C-12 & Conventional & Calibrated Date \\
\hline 154650 & 020 El Laberinto, edge, $75-90 \mathrm{~cm}$ & $2190 \pm 40$ & $-21.43 \%$ & $2250 \pm 40$ & 370 B.C. \\
154651 & 021 El Laberinto, edge, $90-110 \mathrm{~cm}$ & $2470 \pm 40$ & $-21.3 \%$ 0. & $2530 \pm 40$ & 780 в.C. \\
154652 & 036 El Ramonal, center, $65-85 \mathrm{~cm}$ & $1580 \pm 40$ & $-23.23 \%$ & $1610 \pm 40$ & A.D. 430 \\
154653 & 012 Hulubal, edge, $60-70 \mathrm{~cm}$ & $1970 \pm 40$ & $-22.13 \%$ B.C. & $2020 \pm 40$ & 30 B. \\
\hline \hline
\end{tabular}


metal horizon. If that horizon represents the Preclassic soil surface in the other cores, then Hulubal has no criterion that limits how old this date should be. The presence of a sulfur-calcium horizon suggests that it contains slump. (This is the non-surface layer sample that the phytolith analyst identified as having the most visible carbon in the phytolith slides.)

The calibrated date was 30 B.C. As in Sample 020, this could be early for slumping, or, as below nearby El Laberinto, it could be the product of an earlier-than-expected incident of slumping. This is \pm 300 years earlier than the Early Classic date for this phenomenon below Calakmul.

The results of the radiocarbon analysis generally support the assumption that the lower heavy-metal horizon represents the Pre- classic stable surface. The dates are earlier than might have been expected, predating a similar phenomenon below Calakmul. It may be that slumping occurred earlier than expected. Another possibility is that the mean residence time of the stable surface is significantly older than the cultural occupation-that is, it does not indicate the time the surface was buried but, because of older carbon, averages to some earlier date. One might suppose that if the organics in tropical ecosystems were in the mast, this condition would be mitigated. Only additional dates on secure cultural associates at this site will resolve this question.

When the OCR and AMS dates are plotted on core profiles (Figure 6), it becomes clear that the discrepancies between the two are substantial. Because the radiocarbon dates are part of a radiation-

\section{El Laberinto Ridge}

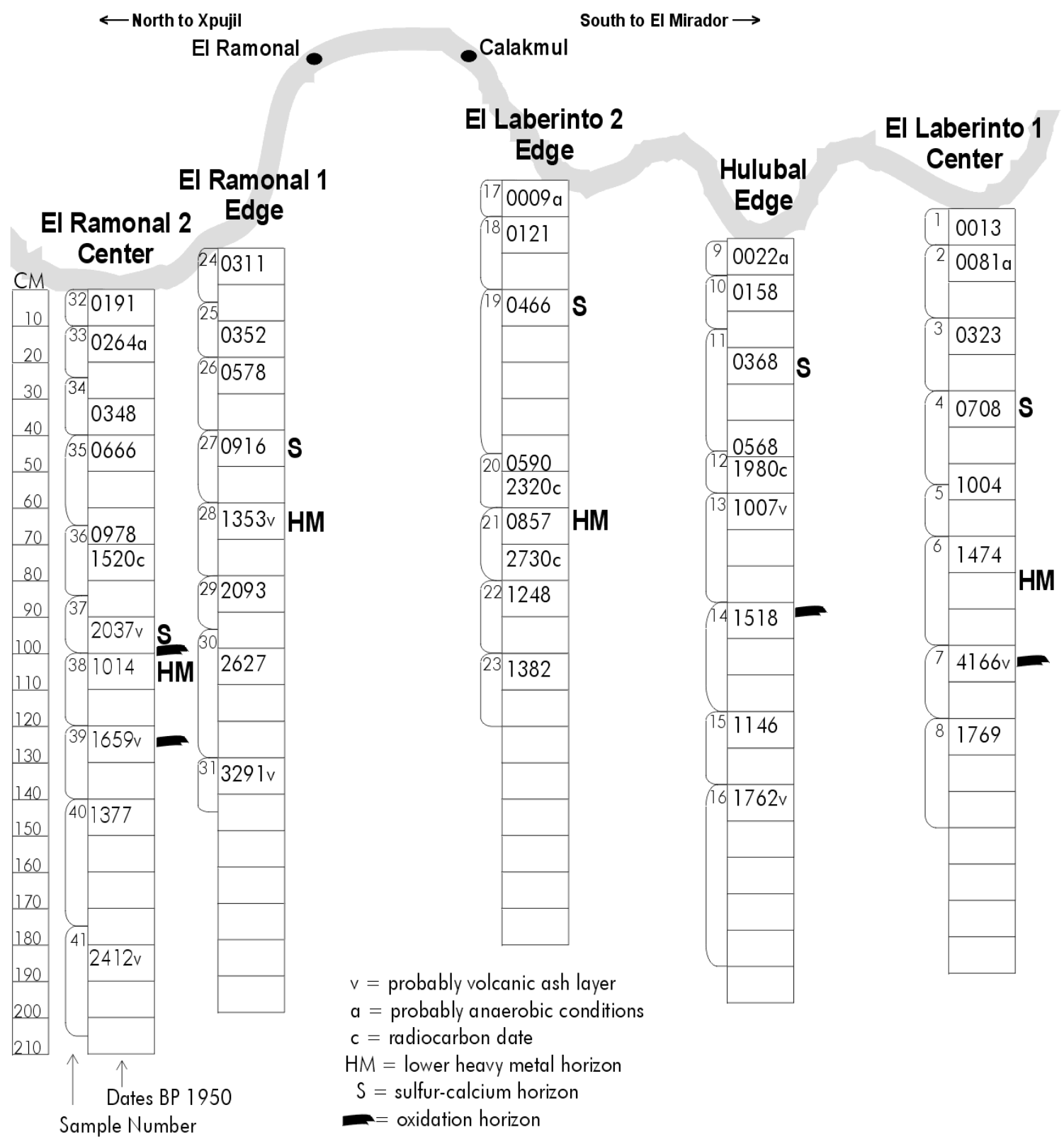

Figure 6. Depth of radiocarbon and OCR dates from cores. 
decay process, they would be expected to be more accurate than the OCR dates, which are dependent on degradation of carbon in an aerobic environment. The OCR determination in Ramonal 2 is $64 \%$ of the radiocarbon age, whereas all three dates in the El Laberinto bajo are around $25-30 \%$ of the radiocarbon age. If the discrepancies are caused by something as simple as annual duration of anaerobic conditions, perhaps the El Ramonal bajo is much less anaerobic than El Laberinto. In fact, we know from observation that the El Ramonal bajo is better drained than El Laberinto.

It would be of value to know the dates of the bottoms of the cores. If the percentage figures given earlier are taken as a correction factor for the OCR dates, a corrected OCR date can be calculated for the deepest core OCR date in each core (Table 8). This would be a function that equalizes the OCR dates to the radiocarbon dates in the sampled bajo.

Although nothing conclusive can be said from this small suite of dates, the corrected OCR dates do indicate that the sediments in the bajos are no older than the Middle or Late Holocene. It suggests that these two high bajos were scoured out by excessive precipitation in the Middle Holocene, and that present-day stable sediments are a product of Late Holocene accumulation processes. This inference is reinforced by the observation that lake levels in the peninsula were unusually high during the Middle Holocene (Mark Brenner, personal communication 2001), and that the Candelaria Regional Climate model (Gunn et al. 1995) predicts higher-than-present precipitation in the Middle Holocene.

\section{Phytolith Analysis}

Because of the time-consuming preparation and expense of the phytolith analysis, only 13 of the 41 samples could be analyzed. A set of variables was coded from the analyst's commentary of the samples (Table 9). Residues were present in the samples that in some cases were impossible to remove fully. Representative samples were selected from all of the cores and strata within cores to provide broad characterizations of strata. By doing so, the phytolith determinations could be extended to other samples within strata. This is not as desirable an option as exhaustive analysis, but it avoids loss of data in the other, more highly resolved analyses due to missing data points.

The frequency of phytoliths varied from abundant to sterile across the samples. Grass phytoliths were observed; all were of the large-grass-cell types, suggesting that at least some of the sediments were of alluvial origin. This assumption was supported in several cases by the presence of moisture indicators such as diatom spicules. Most of the vegetation seems to have been can-

Table 8. OCR anaerobic corrections for core bottoms ${ }^{\mathrm{a}}$

\begin{tabular}{lcc}
\hline \hline Core & Bottom Date & Corrected Bottom Date \\
\hline Ramonal 2 & 2412 B.P. & 3739 в.P. \\
Ramonal 1 & 3291 B.P. & 5101 в.P. \\
Laberinto 2 & 1382 в.P. & 4936 в.P. \\
Hulubal & 1762 в.P. & 6293 в.P. \\
Laberinto 1 & 1769 в.P. & 6318 в.P. \\
\hline
\end{tabular}

${ }^{\mathrm{a}}$ El Laberinto correction $=1.55 \times \mathrm{OCR}$, El Ramonal correction $=3.57 \times \mathrm{OCR}$, correction factor $=(\mathrm{C}-14 / \mathrm{OCR})$.
Table 9. Variables coded from phytolith samples

\begin{tabular}{lll}
\hline \hline Variable Name & \multicolumn{1}{c}{ Description } & \multicolumn{1}{c}{ Codes } \\
\hline No. & Sample number & Number \\
Depth & Depth in centimeters & Depth \\
PhH ${ }_{2} \mathrm{O}$ & Sediment $\mathrm{pH}$ & $\mathrm{pH}$ value \\
PhytExtrap & Phytolith data, original observations & $2=$ extrapolated \\
& $\quad$ or extrapolated to stratum & $1=$ original \\
Diatom & Diatom presence & $2=$ present \\
& & $1=$ absent \\
Black perforated & Black perforated & $3=$ abundant \\
\multicolumn{1}{c}{ segments } & segments concentration & $2=$ present \\
& & $1=$ absent \\
Grass & Grass concentration & $3=$ abundant \\
& & $2=$ present \\
Non-grass & Non-grass concentration & $1=$ absent \\
& & $3=$ abundant \\
& & $2=$ present \\
Alluvial & Alluvial indicators & $1=$ absent \\
& & $2=$ present \\
Clay & Clay concentration & $1=$ absent \\
& & $3=$ heavy \\
Phytoliths & Phytolith concentration & $2=$ present \\
& & $1=$ absent \\
& & $3=$ high \\
Ash & Ash & $2=$ low \\
Grass & & $1=$ none \\
Comments & & $2=$ present \\
& & $1=$ absent \\
& & $2=$ present \\
& $1=$ absent \\
& &
\end{tabular}

opy, making the occasional presence of grass and possible open water of interest.

\section{PATTERN RECOGNITION IN CORE DATA}

A data set as complex as the one aggregated in the foregoing sections requires methods other than casual inspection to detect underlying associations and repeated patterns. A factor analysis was used to reduce this highly replicated data set to its smallest number of dimensions. A factor analysis (principal components analysis) of the data set (Table 10) revealed eight factors (85\% of variance) that represent multiple variables. Factor scores (Table 11) were used to detect the core and depth locations of geochemical, sedimentological, and phytophysical patterns. Important scores are those with numbers greater than 1 or less than -1 (that is, $\mathrm{z}$-scores greater than 1 standard deviation from the mean). Important scores are indicated by underscoring (Table 11).

Three types of patterns are immediately apparent (Figure 7). In the first factor, a trend pattern appears in each core. Trends grade from positive at the top to negative at the bottom. Factor scores for Factors 2-4 have a solid rank of negative scores in one core and occasional oppositely signed scores in isolated levels of other cores. We will refer to this as the bar and dot patterns. Factors 5-7 have only isolated important scores rather than blocks of scores, and this will be referred to as dot patterns. 
Table 10. Factors from combined analysis ${ }^{\mathrm{a}}$

\begin{tabular}{|c|c|c|c|c|c|c|c|c|c|}
\hline Factor name & Deep bases & Basic silicon & Coarse sodium & $\begin{array}{l}\text { Phytolith } \\
\text { chemicals }\end{array}$ & Coarse ash & $\begin{array}{l}\text { Volcanic } \\
\text { organic ash }\end{array}$ & $\begin{array}{l}\text { Anaerobic, } \\
\text { no cadmium }\end{array}$ & Unique & Communalities \\
\hline Active agent & Chemical & Chemical & Mechanical & Life & Mechanical & Volcanic & Anaerobic & - & \\
\hline Component & 1 & 2 & 3 & 4 & 5 & 6 & 7 & 8 & \\
\hline \multicolumn{10}{|l|}{ Variable } \\
\hline Depth & -.86 & -.01 & .22 & .18 & -.16 & -.02 & .20 & -.08 & .90 \\
\hline $\mathrm{pH} / \mathrm{OCR}$ & -.63 & .57 & -.24 & -.04 & .08 & .13 & .12 & .30 & .91 \\
\hline $\mathrm{pH} / \mathrm{H}_{2} \mathrm{O}$ & -.42 & .79 & -.20 & -.12 & .05 & .11 & -.04 & -.13 & .90 \\
\hline$\%$ Organic carbon &.$\underline{.55}$ & -.23 & .35 & -.01 & .17 & .58 & -.13 & -.21 & .91 \\
\hline OCRDATE & $-\overline{.75}$ & -.22 & .32 & -.21 & -.23 &.$\overline{16}$ & .15 & -.09 & .87 \\
\hline Volcanic $^{\mathrm{b}}$ & -.48 & -.10 & .26 & .04 & -.33 & .43 & .20 & -.24 & .70 \\
\hline Anaerobic $^{b}$ & .03 & -.01 & .00 & -.10 & .54 & .20 & $\underline{-.66}$ & .02 & .77 \\
\hline Coarse & -.25 & .23 & .50 & .05 & .67 & -.18 & .00 & .12 & .87 \\
\hline Fine & .25 & -.14 & $-\overline{49}$ & .09 & $-\overline{71}$ & .29 & -.10 & .07 & .94 \\
\hline Very fine & .19 & -.26 & $\overline{-.51}$ & .03 & $\overline{-.65}$ & .25 & -.19 & .12 & .91 \\
\hline Aluminum (Al) & .49 & .82 & .06 & .22 & -.11 & -.02 & -.10 & -.03 & .98 \\
\hline Boron (B) & -.32 & .18 & .64 & .44 & -.17 & .12 & -.07 & .24 & .85 \\
\hline Barium (Ba) & .38 & .64 &.$- \overline{36}$ & $\underline{-. \overline{40}}$ & .07 & -.01 & .00 & .16 & .88 \\
\hline Calcium $(\mathrm{Ca})$ & -.55 & .53 & -.36 & -.40 & -.02 & -.17 & .00 & -.02 & .89 \\
\hline Cadmium (Cd) &. .44 & .06 & .12 & $\overline{-.19}$ & -.02 & -.16 & .66 & .05 & .72 \\
\hline Cobalt (Co) & .74 & .38 & .33 & -.32 & -.05 & .10 & .17 & .09 & .96 \\
\hline Chromium (Cr) & -.27 & .65 & -.35 & .36 & .25 & .15 & .04 & -.09 & .84 \\
\hline Copper $(\mathrm{Cu})$ & .62 & -.58 & -.14 & .05 & .10 & -.02 & .20 & .24 & .86 \\
\hline Iron $(\mathrm{Fe})$ & .83 & $\overline{-.17}$ & .10 & .30 & -.02 & -.14 & -.07 & -.25 & .91 \\
\hline Potassium (K) & .27 & .66 & -.06 & .29 & .17 & .39 & .26 & -.23 & .90 \\
\hline Magnesium $(\mathrm{Mg})$ & .04 & .51 & .19 & .76 & -.14 & -.01 & -.03 & .16 & .91 \\
\hline Manganese (Mn) & .67 & .36 & .31 & -.39 & -.09 & .07 & .26 & .13 & .92 \\
\hline Sodium (Na) & $-\overline{34}$ & .09 & .52 & .69 & -.20 & -.06 & -.02 & .19 & .94 \\
\hline Nickel (Ni) & .45 & .57 & .28 & -.09 & .00 & .43 & -.01 & .25 & .87 \\
\hline Lead $(\mathrm{Pb})$ & .76 & .22 & .28 & -.05 & -.14 &.$- \overline{17}$ & -.05 & -.33 & .86 \\
\hline Sulfur (S) & $-\overline{40}$ & -.39 & .47 & -.32 & .23 & .37 & .08 & -.05 & .83 \\
\hline Silicon $(\mathrm{Si})$ & .03 & .91 & -.07 & -.09 & -.22 & -.24 & -.15 & -.02 & .97 \\
\hline Strontium (Sr) & -.25 & .16 & -.62 & .44 & .25 & .03 & .33 & -.18 & .87 \\
\hline Zinc $(\mathrm{Zn})$ & .90 & .23 & .10 & .26 & .03 & .03 & -.02 & -.03 & .94 \\
\hline Phytoliths ${ }^{c}$ & .37 & -.44 & -.36 & .48 & .24 & -.16 & .10 & -.10 & .79 \\
\hline $\mathrm{Ash}^{\mathrm{b}}$ & .02 & $\overline{-.06}$ & -.57 & .08 & .41 & .50 & .12 & .09 & .78 \\
\hline Grass $^{b}$ & .34 & -.62 & $\overline{-.23}$ & .21 &.$\overline{21}$ & $\overline{.07}$ & .12 & .34 & .77 \\
\hline Eigenvalue & 8.0 & 6.4 & 3.8 & 3.0 & 2.6 & 1.8 & 1.5 & .9 & \\
\hline$\%$ Variance & 24.9 & 19.9 & 12.0 & 9.3 & 8.0 & 5.5 & 4.6 & 3.0 & \\
\hline$\%$ Cumulative variance & 24.9 & 44.8 & 56.8 & 66.1 & 74.2 & 79.7 & 84.3 & 87.2 & \\
\hline
\end{tabular}

Note: Underscored numbers indicate important relationships.

axtraction method: principal component analysis; $\mathrm{pH}$ : $0=$ acid, $7=$ neutral, $14=$ basic.

${ }^{\mathrm{b}} 1=$ no, $2=$ yes.

${ }^{\mathrm{c}} 1=$ no, 2 = low, 3 = high.

The factors will be discussed in the order of their importance (percentage of variance; see the bottom of Table 10) - that is, their impact on the total picture of bajo sediments exposed by the data-collection effort.

\section{TREND PATTERNS}

\section{Core Depth Trends (24.9\%)}

The first factor, and therefore the most prominent pattern across the suite of cores, represents about one-quarter of the variance content of all the cores. The factor correlates strongly with depth
$(-.86)$. It captures the shared vertical patterns across all the cores. Across all cores, $\mathrm{pH}$ increases with depth $(-.63$ and -.42$)$ - that is, deeper sediments become more basic. Also calcium $(\mathrm{Ca},-.55)$ and sulfur $(S,-.40)$, a constituent of gypsum, increase with depth $(-.86)$.

This trend pattern corresponds to field observations that virtually all of the cores tended to become dominantly gypsum crystals toward the bottom. As might be expected, the percentage of organic content (.55) is greater toward the top (note inverse correlation to depth), marking the top soil. Ten heavy elements tend to concentrate toward the top of the cores (aluminum, cadmium, copper, iron, manganese, nickel, lead, and zinc). This signals a weathered sur- 
Table 11. Factor scores from combined factor analysis

\begin{tabular}{|c|c|c|c|c|c|c|c|c|c|c|}
\hline Factor no. & & & & 1 & 2 & 3 & 4 & 5 & 6 & 7 \\
\hline Factor name & $\begin{array}{c}\text { Sample } \\
\text { no. }\end{array}$ & $\begin{array}{c}\text { Core } \\
\text { no. }\end{array}$ & Depth & $\begin{array}{l}\text { Deep } \\
\text { bases }\end{array}$ & $\begin{array}{l}\text { Basic } \\
\text { silicon }\end{array}$ & $\begin{array}{l}\text { Coarse } \\
\text { sodium }\end{array}$ & $\begin{array}{l}\text { Phytolith } \\
\text { chemicals }\end{array}$ & $\begin{array}{c}\text { Coarse } \\
\text { ash }\end{array}$ & $\begin{array}{c}\text { Volcanic } \\
\text { organic ash }\end{array}$ & $\begin{array}{l}\text { Anaerobic, } \\
\text { no cadmium }\end{array}$ \\
\hline \multicolumn{11}{|l|}{ Core name } \\
\hline P2 El Laberinto 1 (center) & 1 & 1 & $0-10$ & 1.68 & -2.14 & .22 & .36 & .66 & -1.58 & 1.79 \\
\hline P2 El Laberinto 1 (center) & 2 & 1 & $10-30$ & .90 & -1.70 & -.12 & .21 & -1.08 & -.52 & -1.13 \\
\hline P2 El Laberinto 1 (center) & 3 & 1 & $30-50$ & .48 & -1.76 & .49 & .29 & .19 & -1.00 & -.59 \\
\hline P2 El Laberinto 1 (center) & 4 & 1 & $50-75$ & .20 & -1.46 & .74 & .44 & .53 & -.04 & -.46 \\
\hline P2 El Laberinto 1 (center) & 5 & 1 & $75-90$ & -.05 & -1.49 & .91 & .50 & .94 & .14 & -.51 \\
\hline P2 El Laberinto 1 (center) & 6 & 1 & $90-120$ & -.23 & -1.47 & .24 & .41 & .78 & .14 & .96 \\
\hline P2 El Laberinto 1 (center) & 7 & 1 & $120-140$ & -1.27 & -1.95 & -.79 & -.76 & -.29 & 1.06 & 1.70 \\
\hline P2 El Laberinto 1 (center) & 8 & 1 & $140-170$ & -1.13 & -2.02 & -.71 & -1.19 & -2.12 & .23 & .64 \\
\hline P6 El Laberinto 2 (edge) & 17 & 2 & $0-10$ & 1.78 & .12 & .43 & .44 & -.74 & 2.05 & -.85 \\
\hline P6 El Laberinto 2 (edge) & 18 & 2 & $10-30$ & 1.08 & -.20 & 1.15 & .56 & .48 & 1.67 & -.77 \\
\hline P6 El Laberinto 2 (edge) & 19 & 2 & $30-75$ & .00 & .41 & 1.94 & -.13 & .50 & .51 & -.40 \\
\hline P6 El Laberinto 2 (edge) & 20 & 2 & $75-90$ & -.46 & .98 & .63 & -.11 & -2.07 & -.80 & -.40 \\
\hline P6 El Laberinto 2 (edge) & 21 & 2 & $90-110$ & -.40 & .86 & 1.40 & .18 & .23 & -.11 & .02 \\
\hline P6 El Laberinto 2 (edge) & 22 & 2 & $110-130$ & -.73 & .65 & 1.45 & .14 & .51 & -.06 & .05 \\
\hline P6 El Laberinto 2 (edge) & 23 & 2 & $130-150$ & -.67 & .69 & .31 & .33 & -.96 & -1.79 & 2.21 \\
\hline P4 Hulubal (edge) & 9 & 3 & $0-10$ & .97 & .23 & .40 & .22 & -1.88 & 1.65 & .05 \\
\hline P4 Hulubal (edge) & 10 & 3 & $10-25$ & .34 & .04 & 1.39 & .03 & -.50 & .95 & .63 \\
\hline P4 Hulubal (edge) & 11 & 3 & $25-60$ & .04 & .44 & 1.28 & .16 & -.49 & .64 & .49 \\
\hline P4 Hulubal (edge) & 12 & 3 & $60-70$ & -.32 & .56 & .60 & .20 & -1.85 & .20 & .19 \\
\hline P4 Hulubal (edge) & 13 & 3 & $70-100$ & -.72 & .59 & 1.01 & .41 & -.27 & 1.00 & .67 \\
\hline P4 Hulubal (edge) & 14 & 3 & $100-130$ & -.95 & .53 & .42 & .74 & .40 & .22 & .53 \\
\hline P4 Hulubal (edge) & 15 & 3 & $130-150$ & -.70 & .97 & -.18 & 1.05 & -1.18 & -1.27 & 1.14 \\
\hline P4 Hulubal (edge) & 16 & 3 & $150-200$ & -.95 & .63 & .33 & 1.27 & 1.20 & -.09 & 1.31 \\
\hline P8 El Ramonal 1 (edge) & 24 & 4 & $0-15$ & 2.67 & 1.69 & -.97 & -2.05 & 1.54 & 1.03 & 2.69 \\
\hline P8 El Ramonal 1 (edge) & 25 & 4 & $15-30$ & 1.12 & 1.35 & -.90 & -1.52 & -.82 & -.26 & -.47 \\
\hline P8 El Ramonal 1 (edge) & 26 & 4 & $30-50$ & .10 & .90 & .60 & -1.40 & .77 & -.58 & -1.30 \\
\hline P8 El Ramonal 1 (edge) & 27 & 4 & $50-70$ & -.73 & .64 & .27 & -1.54 & .56 & -.68 & -.75 \\
\hline P8 El Ramonal 1 (edge) & 28 & 4 & $70-90$ & -.51 & .68 & -.12 & -1.60 & -.27 & -1.21 & -.08 \\
\hline P8 El Ramonal 1 (edge) & 29 & 4 & $90-105$ & -.73 & .33 & .58 & -1.45 & 1.30 & -.82 & -.98 \\
\hline P8 El Ramonal 1 (edge) & 30 & 4 & $105-140$ & -1.25 & -.22 & .18 & -1.66 & .85 & -.86 & -.79 \\
\hline P8 El Ramonal 1 (edge) & 31 & 4 & $140-155$ & -1.30 & -1.24 & -.99 & -2.07 & .27 & 1.35 & -.77 \\
\hline P10 El Ramonal 2 (center) & 32 & 5 & $0-10$ & 1.55 & -.12 & -1.41 & -.14 & -.93 & -1.69 & .43 \\
\hline P10 El Ramonal 2 (center) & 33 & 5 & $10-25$ & 1.73 & -.21 & -.94 & -.12 & .27 & -1.02 & -.36 \\
\hline P10 El Ramonal 2 (center) & 34 & 5 & $25-40$ & 1.10 & -.01 & -.49 & .42 & .82 & -.60 & -1.59 \\
\hline P10 El Ramonal 2 (center) & 35 & 5 & $40-65$ & .72 & .08 & -.14 & 1.18 & .57 & -.42 & -1.03 \\
\hline P10 El Ramonal 2 (center) & 36 & 5 & $65-85$ & .50 & .36 & -.85 & 1.67 & -.18 & -.12 & -.81 \\
\hline P10 El Ramonal 2 (center) & 37 & 5 & $85-100$ & -.58 & .28 & -2.30 & -.20 & -.24 & 2.32 & -.16 \\
\hline P10 El Ramonal 2 (center) & 38 & 5 & $100-120$ & -.80 & .59 & -1.57 & .79 & -.84 & .02 & -1.48 \\
\hline P10 El Ramonal 2 (center) & 39 & 5 & $120-140$ & -.74 & .56 & -1.51 & 1.45 & 1.37 & .37 & .37 \\
\hline P10 El Ramonal 2 (center) & 40 & 5 & $140-175$ & -.73 & .79 & -1.65 & 1.55 & .01 & -.54 & -.69 \\
\hline P10 El Ramonal 2 (center) & 41 & 5 & $175-205$ & -1.02 & .02 & -1.31 & .90 & 1.94 & .53 & .49 \\
\hline
\end{tabular}

Note: Boldface numbers indicate important scores.

faces on which heavier elements have concentrated in the top soil as the more soluble and mobile elements were removed into solution.

The factor scores (Table 11, Factor 1) show that all of the cores have this fundamental background pattern of becoming more basic down-core (see bold cells under Factor 1 in Table 11). El Laberinto 1 and El Ramonal 2, both center cores, are mostly acidic, while the edge cores in both bajos are all basic at the top and become more so down-core. El Laberinto 1 is overall the most acidic corel, being acidic from top to bottom.

As can be seen in Figure 8, the edge and center cores vary in conformity of the trend to the ideal diagonal pattern. The center cores maintain a relatively steady trend toward basic chemistry toward the bottom; they follow the "normal trend line" down the diagonal of the graph. The edge cores, however, dogleg rapidly down toward basic chemistry, labeled "rush to base" in the figure. They remain basic through the rest of their depth. As will be demonstrated in other factors to follow, this tendency seems to be a product of human intervention through deforestation and sediment denudation of nearby uplands, resulting in deposition of calcium in the bajo edge. Various manifestations of this process can be observed in a number of patterns and geochemical relationships in the factor scores. It also corresponds to similar processes 
Factor Score Patterns in Table B7 TREND BARANDDOT DOT
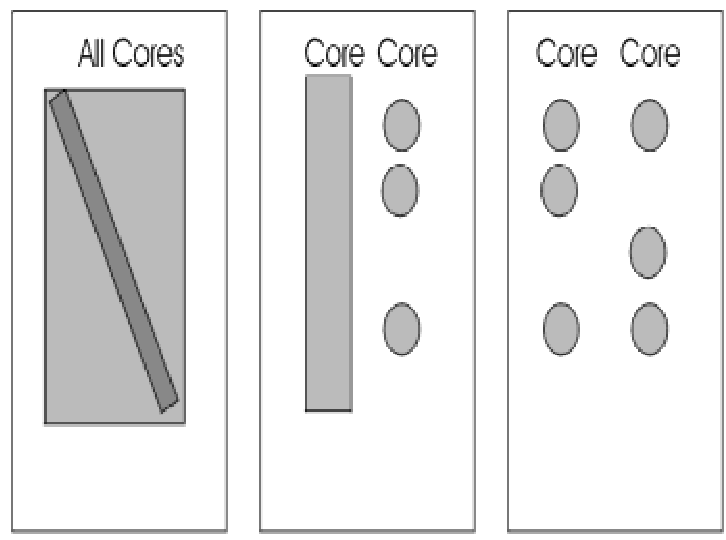

Figure 7. Patterns of factor scores in core profiles.

observed in other bajos in other parts of the Maya Lowlands (see Dunning et al. 2000; Jacob 1995).

In addition to these trends, heavy elements show spotty distributions that are helpful in interpreting the core profiles. Examination of the data (in Gunn et al. 2000) shows some interesting conditions that are replicated across most of the cores. Taking lead $(\mathrm{Pb})$ to represent heavy elements found in presumed weathering horizons, secondary peaks of lead occur at five to six samples down from the surface (Table 12). Also, in most cases a sulfur and calcium secondary peak occurs above the lead peak. If the lead peak is taken to represent a buried soil (weathering horizon), and the sulfur and calcium slumped bajo edge soils/sediments, then they could represent the typical sequence seen in other bajos and at Calakmul, where the Preclassic and before sediments are "natural" old buried soils, and those after are sediments generated by anthropogenically instigated erosion of uplands and deposition on the bajo edge. As discussed earlier, the slump soils date to the Late Preclassic and Classic periods.

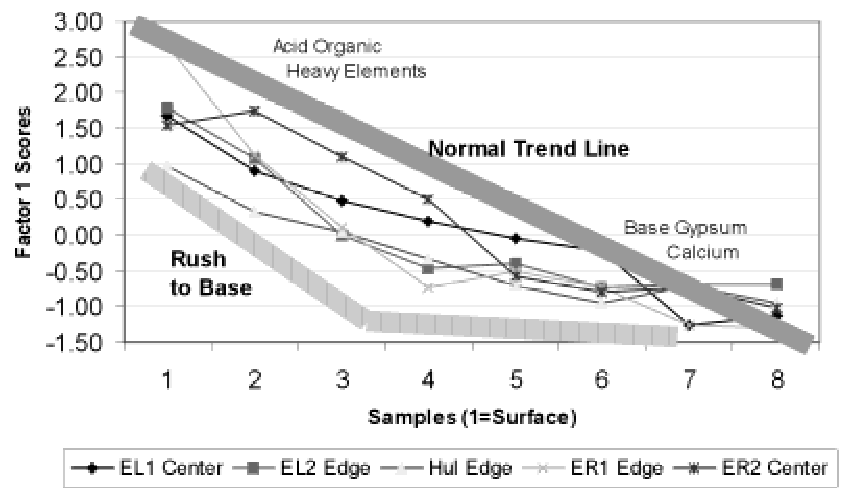

Figure 8. Trend patterns of Factor 1 scores. All cores are more acidic, organic, and rich in heavy elements at the top. They then become basic and dominated by gypsum and calcium at the bottom. EL, El Laberinto; ER, El Ramonal; Hul, Hulubal.
Table 12. Lead and sulfur secondary peaks in cores and OCR dates ${ }^{\mathrm{a}}$

\begin{tabular}{lccc}
\hline \hline Core & $\begin{array}{c}\text { Lead } \\
\text { Peak } \\
\text { Sample }\end{array}$ & $\begin{array}{c}\text { Sulfur } \\
\text { Peak } \\
\text { Sample }\end{array}$ & \multicolumn{1}{c}{ Comment } \\
\hline EL1 center & 6 & 4 & $\begin{array}{c}\text { It is especially noteworthy that the } \\
\text { center cores, especially Ramonal 2 } \\
\text { center, show this pattern }\end{array}$ \\
EL2 edge & 21 & 19 & $\begin{array}{c}\text { Hulubal has no lead through the } \\
\text { Hul edge }\end{array}$ \\
No lead & 11 & & \\
ER1 edge & 28 & 27 & (n) prile \\
ER2 center & 38 & 37 & \\
\hline \hline
\end{tabular}

aAll sulfur peaks have equivalent calcium peaks.

In summary, all cores demonstrate trends from top to bottom. The tops of cores tend to be an acidic-organic mix rich in heavy elements, while the bottoms are largely gypsum and are more basic. Secondary peaks of heavy elements may be buried soils paralleling those found in bajos in the Lake District of Guatemala and south of Calakmul.

Bar and dot patterns. Factors 2-4 each delineate one core with a solid array of important scores, while on the same factor the other cores have only intermittent scores, the bar and dot pattern (Table 11). The reason the relationships fall out in this fashion is clearer in some cases than others.

In Factor 2, scores represent contrasting conditions between the whole of El Laberinto 1 center core (bar) and the top of El Ramonal 1 edge core (dots). The finding is that acidic samples in the case of the EL1 core have more phytoliths; basic samples in ER1 have few.

The pattern in Cores 3 and 4 is much more complex and interesting. The entire length of one core, in each case, contrasts with isolated samples in other cores. Inspection reveals that these isolated samples correspond to the lead and sulfur peaks noted in discussion of the previous factor. This suggests that the dots could be the products of anthropogenic modification of bajo ecology.

In the following discussions of bar and dot factors, this possibility will be examined. (For a detailed discussion of the factor's constituents, see Gunn et al 2000.)

\section{Grass and Soils $(19.9 \%)$}

Factor 2 represents the second-most-powerful influence on the stratigraphic milieu of the bajo cores. It is dominated by $\mathrm{pH}$. The pattern suggests that the center of the El Laberinto bajo (Core 1) is different from the others in that it is more acidic than the others and has little to offer in terms of association with elements except copper. It does have large grass phytoliths. This suite of characteristics combine in close association to yield the bar pattern in El Laberinto 1 center. The other cores, especially those from El Ramonal, are more basic in $\mathrm{pH}$ and enriched by a wide range of elements - notably, silicon and sulfur (gypsum) — in isolated levels. The isolated levels with this dot pattern may represent buried weathering surfaces or some other, perhaps related, concentrating process. 


\section{Grain-Size Cities (12\%)}

Factor 3 also has the bar and dot pattern, this time with El Ramonal 1 edge providing a solid bar contrast to isolated (dot) levels in other cores. The isolated levels in the Factor 3 dot pattern may be the result of past anthropogenic effects on the landscape; the factor has no systematic relationship to depth and is associated with salt and gypsum. The latter would have migrated upward in the soil column during times of deforestation and moisture stress or laterally through coarse-grained strata. This factor contrasts the two bajos. Isolated levels are found near the edge in the heavily occupied El Laberinto bajo, whereas the less-occupied El Ramonal exhibits a profilewide association of fine-grained, strontium-laced sediments. Anthropogenic influence in the center of El Ramonal seems to have been expressed as an influx of very fine (suspended?) particles.

\section{Salty Metals: Barium (9.3\%)}

The last bar and dot patterned factor associates phytoliths with boron $(\mathrm{B})$, magnesium $(\mathrm{Mg})$, sodium $(\mathrm{Na})$, and strontium $(\mathrm{Sr})$ on its positive pole. The percentage of variance accounted for by Factor 4 is falling below $10 \%$, suggesting that cautious interpretation is in order. The associations it generates are not immediately illuminating, with the possible exception of the negative relationship between barium and calcium in the El Ramonal edge core. Calcium is probably an indicator of levels with slump sediment, whereas barium levels could be associated with humans concentrating plant material. Perhaps future research will add to our understanding of this factor.

Dot patterns. The dot-pattern factors (5-8) did not provide immediately useful information. This is normal for factor-analysis factors associated with single variables, called "uniques." The insight they yield is which variables are not providing common relationships between cores. Notable among these is anaerobic conditions, which loads on Factor 7. Anaerobic conditions appear to have no particular influence on the interactions in the system.

\section{CONCLUSIONS}

This study concludes that, despite any vertic processes that may have occurred, the sediments retain enough integrity to exhibit stratification. The bajo sediments we examined appear to have begun their present cycle of accumulation during the Middle Late Holocene, basically the past 4,000-5,000 years. Because this also frames the evidence of Maya settlement in the peninsular lowlands, it is possible that the conditions of the bajos provided the critical opportunities and liabilities encountered by Maya settlers as they began their journey to civilization. Other dates, such as a stable sediment body with a weathering horizon until the Preclassic and the slumping of upland sediments into bajo margins during the Late Preclassic or Classic period, also broadly meet the expectations of cultural chronology and, perhaps, will add insight as more is known. Finally, the sequence of a moist Middle Holocene and a drier, droughtprone Late Holocene parallels inferences drawn from global-climate parameters and river discharge in our previous studies.

This research indicates that the bajo edge was not usable as a water-storage and horticultural surface until after it was, by accident or intention, modified by human occupation of adjoining uplands. Masonry-bottom aguadas must also have been involved in this adaptation. (This pattern represents a reversal of what was dis- covered at Nakbe by Hansen [1998; Jacob 1995] and perhaps explains Calakmul's continued occupation into the Classic period.) After a limy layer of sediment was laid down on the old saline sediments in Calakmul, it was used for both crops and water storage, but the subsurface levels were avoided by imposing intervening masonry construction. This expanded water-storage capacity may have provided the additional water resources necessary to support the more substantial ruling elite of the Classic period and their inclination for construction (requiring dry-season water) and intensive population aggregation (requiring water for domestic uses). A similar increase in Classic-period population based on increased reservoir capacity was observed at Edzna (Andrews 1984).

The geochemistry of both this study and other studies such as Barbara Leyden's (1987) of brackish Lake Salpeten suggest that, before anthropogenic modification, the southern interior Yucatan Peninsula was a geochemically hostile environment—at least, as far as large urban aggregates were concerned. Saline lakes and bajos contaminated with gypsum would have been potable for only part of the year, at most, precluding permanent urban settlements. Under these conditions, establishing permanent occupation would have more resembled settlement on the moon or Antarctica than most other terrestrial habitats. Occupation of a new region would have required, minimally, transportable engineering based on an understanding of large water systems and advanced parties to develop the rudiments of hydrological infrastructure. This perspective on water supply brings into sharp focus Scarborough's (1998:138) and others' observations that, before the Early Preclassic period, only the estuaries and deltas would have supported permanent populations. Scarborough posits a 500year lag in settlement of the interior, which is further illuminated by Nicholas Dunning's (1996) notes on highly diverse habitats requiring tailored horticultural solutions region by region. All of this highlights the astonishing accomplishment of the Maya in building large cities, and maintaining them, albeit intermittently, for hundreds of years. These permanent, year-round populations could be established only in the presence of an anticipatory engineering of water supplies.

Tikal, like Calakmul, was built on a promontory. Its combination of prepared watersheds, bajo-edge reservoirs, and neighborhood reservoirs (Scarborough and Gallopin 1991) seems to reflect an intermediate level of design between the intense centralization of Edzna and Calakmul's extreme modularization. The modularization of Calakmul's hydrological system, we believe, represents at least part of a solution for adapting to interior upland environments without permanent water sources until the ninth century, when a lack of adequate seasonal rainfall contributed to the downfall of this unique system (Folan 1981; Gunn and Adams 1981; Gunn and Folan 2000; Gunn et al. 1994, 1995; Hodell et al. 1995).

The sediments of the two adjoining Calakmul show similarities and dissimilarities. They provide an overall picture of Vertisols, reflecting the limestone character of the surrounding uplands, and appear to be moist enough seasonally and across the centuries to maintain the fundamental integrity of the strata. This explains the appearance of seemingly invisible pedological strata in the geochemical analyses.

Contrasting elements between cores include differences in calcium-carbonate concentrations between center and margin cores, mottling between bajos, and phytolith distributions in differing pHs. These features seem to indicate that the El Laberinto bajo was exposed to greater seasonal drying (mottles), more overturning of sediments through vertic processes (darker color), and more 
concentration of gypsum (soluble and mobile) toward the center. Because the bajo is directly below Calakmul and a line of other cities flanking its north bank, it can be supposed that these conditions result wholly or partly from anthropogenic sources. This could be related to deforestation by humans in the Classic period, with consequent exposure to evaporative processes.

In sum, our research provides a backdrop for Maya occupation of the elevated interior lowland. It may have been played out according to the following scenario. Most broadly, our study of bajo sediments suggests an across-time picture of increasingly complex interactions between humans and climate and landscape. Initially, people arriving with hydrological engineering skills could have overcome liabilities such as dry-season saline water resources and taken advantage of opportunities to produce wet-season crops in the up- lands. As the Late Holocene proceeded, with its increasing penchant for longer cold periods (little ice ages) locally manifested as drought, and as the Maya stripped the lowlands of non-renewable and very-long-cycle renewable resources, their habitation of the lowlands interior would have become increasingly imperiled on the basis of deteriorating landscape and climate alone. Ironically, at least one of these landscape deteriorations-the slumping of calciumrich upland soils into the bajo edges - provided agricultural opportunities and perhaps extended their tenable stay. Other social liabilities such as warfare, interruption of trade routes, impoverishment of soil nutrients, and overpopulation would have exacerbated relationships with the background conditions. At some point in time, the liabilities would have outstripped the opportunities, and the great cities would have been abandoned.

\section{RESUMEN}

Los investigadores estudiando las tierras bajas mayas han rechazado creencias anteriores de que la civilización maya floreció con un ambiente inalterable. Análisis de la descarga de ríos, patrones de clima, sedimento de los fondos de lagos y patrones de asentamiento revelan un clima variable, diversidad en la geología y suelos locales y un rango grande de adaptaciones culturales ajustados a distintivos escenarios subregionales. Significantes lagunas de conocimiento sobran. Entre las preguntas sin respuestas está averiguar como las ciudades en el interior elevado podrían mantenerse sin cuerpos permanentes de agua natural aún cuando existe un periodo de condiciones climáticas equitativas, mucho menos todavía durante los episodios de sequía severa que han llegado a ser aparentes en los estudios de climas pasados. La investigación reportada en este artículo proporciona la base para estudios climáticos en el sureste de la península de Yucatán.

\section{ACKNOWLEDGMENTS}

The authors thank the Committee for Research and Exploration of the National Geographic Society for supporting our project in all its phases. We also thank Javier de la Maza Elvira of Semarnap de México for permission to sample the El Laberinto and El Ramonal bajos. Raymundo González Heredia, Concepción Pech Cocom, and Carmelo Pech García

\section{REFERENCES}

Adams, Richard E.W

1991 Nucleation of Population and Water Storage Among the Ancient Maya. Science 251:632.

Andrews, George F.

1984 Edzná, Campeche, Mexico: Settlement Patterns and Monumental Architecture. Foundation for Latin American Anthropological Research, Culver City, CA.

Covich, Alan, and M. Struiver

1974 Changes in Oxygen 18 as a Measure of Long-Term fluctuations in Tropical Lake Levels and Molluscan Populations. Limnology and Oceanography 19:682-691.

Dahlin, Bruce H., John F. Foss, and Mary Elizabeth Chambers

1980 Project Acalches: Reconstructing the Natural and Cultural History of a Seasonal Swamp at El Mirador Guatemala; Preliminary Results. In El Mirador, Petén, Guatemala: An Interim Report, edited by Ray Matheny, pp. 34-57. New World Archaeological Foundation, Brigham Young University, Provo, UT.

Domínguez Carrasco, Maria del Rosario

1993 Calakmul, Campeche y su sistema hidráulico. In Los Investigadores de la Cultura Maya, pp. 42-46. Universidad Autónoma de Campeche, Campeche, Mexico.

1994 Calakmul, Campeche: Un análisis de la cerámica. Colección Arqueología 4. Centro de Investigaciones Históricas y Sociales, Universidad Autónoma de Campeche, Campeche, Mexico.

Domínguez Carrasco, Maria del Rosario, and William J. Folan

1996 Calakmul, Mexico: Aguadas, bajos, precipitación y asentamiento en el Petén Campechano. In Proceedings of the IX Simposio de Investigaciones Arqueológicas en Guatemala, edited by J. Laporte and H. Escobedo, pp. 171-193. Museo Nacional de Arqueología y Etnología, Guatemala. made our stay in the bajos more productive and comfortable, and personnel of the Engineering Department of the Universidad Autónoma de Campeche provided coring equipment and field assistance. All errors or omissions are exclusively the authors'.
Domínguez Carrasco, Maria del Rosario, Joel D. Gunn, and William J. Folan

1998 Los Investigadores de la Cultura Maya 5, vol. II, pp. 526-540. Universidad Autónoma de Campeche, Campeche, Mexico.

Dunning, Nicholas

1996 A Reexamination of Regional Variability in the Prehistoric Agricultural Landscape. In The Managed Mosaic: Ancient Maya Agriculture and Resource Use, edited by S. Fedick, pp. 53-68. University of Utah Press, Salt Lake City.

Dunning, Nicholas, David J. Rue, Timothy Beach, Alan Covich, and Alfred Traverse

1998 Human-Environment Interactions in a Tropical Watershed: The Paleoecology of Laguna Tamarindito, El Petén, Guatemala. Journal of Field Archaeology 25:139-151.

Dunning, Nicholas P., Vernon Scarborough, T. Patrick Culbert, John G. Jones, Sheryl Luzzadder-Beach, and Timothy Beach

2000 The Rise of the Bajos and Rise of Maya Civilization. Paper presented at the 65th Annual Meeting of the Society of American Archaeology, Philadelphia.

Faust, Betty B.

1998 Mexican Rural Development and the Plumed Serpent: Technology and Maya Cosmology in the Tropical Forest of Campeche, Mexico. Bergin and Garvey, Westport, CT.

Faust, Betty B., and Joel D. Gunn

2000 Gardens, Ceremony and Climate in the Cultural Memory of a Maya Village. Manuscript on file, Departamento de Ecologia $\mathrm{Hu}-$ mana, Centro de Investigacíon y de Estudios Advanzados-Unidad Merida, Merida, Mexico.

Faust, Betty B., and Abel Morales López

1993 La aguada en la historia oral de Pich, Campeche: Adaptaciones a 
variaciones de clima en un pueblo maya. Paper presented at the 13th International Congress of Anthropological and Ethnological Sciences, Session 314, Mexico, DF.

Folan, William J.

1981 Comments on the Late Postclassic Eastern Frontier of Mesoamerica: Cultural Innovation along the Periphery by J. Fox. Current Anthropology 22:336-337.

Folan, William J., and Silverio Gallegos O.

1992 Uso prehispánico del suelo. In Programa de manejo reserva de la biosfera, Calakmul, Campeche, edited by William J. Folan, Jose Manuel García Ortega, and Maria Consuelo Sánchez González. Universidad Autónoma de Campeche, México. Secretaria de Desarrollo Social.

1998 Uso del suelo en el Estado de Campeche, México y Alrededores. Los Investigadores de la Cultural Maya 5, vol. II, pp. 459-478. Universidad Autónoma de Campeche, Campeche.

Folan, William J., Joel D. Gunnl, and Maria del Rosario Domínguez Carrasco 2001 Triadic Temples, Central Plazas and Dynastic Palaces: A Diachronic Analysis of the Royal Court Complex; Calakmul, Campeche. In Royal Courts of the Ancient Maya, edited by $\mathrm{T}$. Inomata and $\mathrm{S}$. Houston, pp. 223-265, Westview Press, Boulder, CO.

Folan, William J., Jose Manuel García Ortega, and Maria Consuelo Sánchez Gonzalez

1992 Programa de manejo reserva de la biosfera de Calakmul, Campeche. Centro de Investigaciones Históricas y Sociales, Universidad Autónoma de Campeche, Campeche, Mexico.

Folan, William J., Laraine A. Fletcher, J. May Hau, and Lynda Florey Folan

2001 Las Ruinas de Calakmul, Campeche, México: Un lugar central y su paisaje cultural. Appendices A-C. Centro de Investigaciones Históricas y Sociales, Universidad Autónoma de Campeche, Campeche, Mexico.

Folan, William J., Joel Gunn, Jack D. Eaton, and Robert W. Patch

1983 Paleoclimatological Patterning in Southern Mesoamerica. Journal of Field Archaeology 10:453-468.

Folan, William J., Joyce Marcus, Sophia Pincemin, Maria del Rosario

Domínguez Carrasco, Laraine A. Fletcher, and Abel Morales López

1995 Calakmul: New Data from an Ancient Maya Capital in Campeche, Mexico. Latin American Antiquity 6:310-334.

Folan, William J., Abel Morales López, Maria del Rosario Domínguez

Carrasco, Roberto Ruiz G., Raymundo González H., Joel D. Gunn, Lynda

Florey Folan, Manuel Barredo, and José A. Hernández T.

2001 La Ciudad y puerto de Champoton, Campeche: Encrucijada del Golfo de México. In XI Encuentro Internacional: Los Investigadores de la Cultura Maya, vol. I, pp. 8-16. Universidad Autónoma de Campeche, Campeche, Mexico.

Gates, Gary

1999 Fisiografía, geología e hidrología. In Naturaleza y cultura en Calakmul, Campeche, edited by William J. Folan, Maria Consuelo Sánchez Gonzalez, and Jose Manuel García Ortega, pp. 31-39. Centro de Investigaciones Históricas y Sociales, Universidad Autónoma de Campeche, Campeche, Mexico.

Gill, Richard B.

1995 The Great Maya Droughts. Ph.D. dissertation, Department of Anthropology, University of Texas, Austin.

2000 The Great Maya Droughts: Water, Life, and Death. University of New Mexico Press, Albuquerque.

Gunn, Joel D.

1991 Influences of Various Forcing Variables on Global Energy BA.ce during the Period of Intensive Instrumental Observation (19581987) and Their Implications for Paleoclimate. Climatic Change 19:393-420.

1997 A Framework for the Middle-Late Holocene Transition: Astronomical and Geophysical Conditions. Southeastern Archaeologists $16: 134-151$.

Gunn, Joel, and Richard E.W. Adams

1981 Climatic Change, Culture, and Civilization in North America. World Archaeology 13:85-100.

Gunn, Joel, and William J. Folan

2000 Three Rivers: Subregional Variations in Earth System Impacts in the Southwestern Maya Lowlands (Candelaria, Usumacinta, and Champoton Watersheds). In The Way the Wind Blows: Climate, His- tory, and Human Action, edited by R. Mcintosh, S. Mcintosh, and J. Tainter, pp. 223-270. Columbia University Press, New York.

Gunn, Joel, William J. Folan, and Hubert R. Robichaux

1993 Global Climate and Episodic Urbanism in the Maya Lowlands. Paper presented at the 1993 Meeting of the International Union of Archaeological and Ethnological Sciences, Mexico, DF.

1994 Un Análisis informativo sobre la descarga del sistema del Río Candelaria en Campeche, México: Reflexiones acerca de los paleo climas que afectaron a los antiguos sistemas mayas en los sitios de Calakmul y el Mirador. In Campeche Maya Colonial, edited by W. Folan Higgins, pp. 174-197. Colección Arqueología, Universidad Autónoma de Campeche, Mexico.

1995 A Landscape Analysis of the Candelaria Watershed in Mexico: Insights into Paleoclimates Affecting Upland Horticulture in the Southern Yucatan Peninsula Semi-Karst. Geoarchaeology 10:3-42.

Gunn, Joel D., John E. Foss, William J. Folan, Maria del Rosario Domínguez Carrasco, and Betty B. Faust

2000 Elevated Cities in the Central Yucatan Peninsula of Campeche: Research into the Context and Maintenance of Elevated Cites without Natural Permanent Water Supplies. Submitted to the National Geographic Society, Grant 6037-97, Washington, DC.

Hansen, Richard D.

1998 Incipient Maya Wetland Agriculture: Definition of Ancient Systems and Sustainable Application in Contemporary Rainforest Populations. Ms. on file, Institute of Geophysical and Planetary Physics, University of California, Los Angeles, and Foundation for Anthropological Research and Environmental Studies.

Hodell, David A., Jason H. Curtis, and Mark Brenner

1995 Possible Role of Climate in the Collapse of Classic Maya Civilization. Nature 375:391-394.

Jacob, John S.

1995 Archaeological Pedology in the Maya Lowlands. In Pedological Perspective in Archaeology Research, pp. 51-80. Soil Sciences Society of America Special Publication 44. Madison, WI.

Leyden, Barbara W.

1987 Man and Climate in the Maya Lowlands. Quaternary Research 28:407-417.

Leyden, Barbara W., Mark Brenner, David A. Hodell, and Jason H. Curtis 1994 Orbital and Internal Forcing of Climate on the Yucatan Peninsula for the Past ca. 36 ka. Paleogeography, Paleoclimatology, Paleoecology 109:193-210.

Matheny, Ray T., Deanne L. Gurr, Donald W. Forsyth, and Richard Hauck 1983 Investigations at Edzna, Campeche, Mexico: The Hydraulic System. Papers of the New World Archaeology Foundation, No. 46. Brigham Young University Press, Provo, UT.

May Hau, J.

2001 Mapa de las ruinas de Calakmul, Campeche. 32 boxed sheets. In Las ruinas de Calakmul, Campeche, México: Un lugar central y su paisaje cultural, edited by William J. Folan, Laraine A. Fletcher, J. May Hau, and Lynda Florey Folan, Appendices A-C. Centro de Investigaciones Históricas y Sociales, Universidad Autónoma de Campeche, Campeche, Mexico.

Murray, G. E., and A.E. Weide, Jr.

1967 Regional Geologic Summary. of Yucatan Peninsula. In Guidebook, Field Trip to the Peninsula of Yucatan, 2nd ed., edited by A. Weide, Jr. New Orleans Geological Society, New Orleans.

Pohl, Mary, and Paul Bloom

1996 Prehistoric Maya Farming in the Wetland of Northern Belize: More Data from Albion Island and Beyond. In The Managed Mosaic: Ancient Maya Agriculture and Resource Use, edited by S. Fedick, pp. 145-164. University of Utah Press, Salt Lake City.

Scarborough, Vernon L.

1998 Ecology and Ritual: Water Management and the Maya. Latin American Antiquity 9:135-159.

Scarborough, Vernon L., and Gary G. Gallopin

1991 A Water Storage Adaptation in the Maya Lowlands. Science 21:658-662.

Whitmore, Thomas J., Mark Brenner, Jason H. Curtis. Bruce H. Dahlin, and Barbara W. Leyden

1996 Holocene Climatic and Human Influences on Lakes of the Yucatan Peninsula, Mexico: An Interdisciplinary, Palaeolimnological Approach. The Holocene 6:273-287. 